\title{
TMK m. 198 Uyarınca Evlilik Birliğini Koruyucu Önlemin İş İlişkisine Etkileri ve İşçi Alacakları
}

\author{
Gülümden ÜRCAN 1 \\ ORCID: 0000-0002-3460-537x \\ DOI: $10.54752 /$ ct.1060814
}

Öz: Toplumun temeli ailedir. Evlilik birliği hukuk sistemi tarafindan korunmaktadır. Nitekim Türk Medeni Kanunu'nda bu birliği koruyucu çeşitli düzenlemeler bulunmaktadır. Her eş birliğin giderlerine katılmakla yükümlüdür. Eğer eşlerden biri birliğin giderlerine katılma yükümlülügünü yerine getirmez ise, hâkim onun borçlularına ödemeyi kısmen veya tamamen diğer eşe yapmalarını emredebilir. Söz konusu geçici önlem çoğunlukla iş ilişkilerinde uygulanmaktadır. Bu çalışmada, mahkemenin borçlulara yönelik emrinin iş ilişkileri üzerindeki etkileri ve işçi alacakları ele alınacaktır.

Anahtar Kelimeler: Evlilik birliği; giderlere katılma yükümlülüğ̈̈; borçlulara yönelik emirler.

The Effects of Measure related to Marital Union Protection (According to Art. 198 of the Turkish Civil Code) on Labor Relations and Employee Claims.

Abstract: Family is the fundamental structure of society. The marital union is protected by the legal system. As a matter of fact, the Turkish Civil Code (TCC) contains various regulations which aim to protect this union. Each spouse is under the debt of participating in the expenses of the marital union. If one of the spouses fail to fulfill the obligation to participate in the expenses of the marital union, the court may order his or her debtors to make the payment to the other spouse, in whole or in part (TCC Art. 198). In practice, this temporary measure is mostly applied in the labor relations. In this article, the court's order of measure regarding the debtors of the spouses will be discussed, in terms of its legal effects on labor relations and employee claims.

Keywords: Marital union; duty to participate in the expenses; directions to debtors.

${ }^{1}$ Dr. Öğr. Üyesi, DEÜ. İİBF. Hukuk Bilimleri ABD. Öğretim Üyesi

Makale Geliş Tarihi:26.05.2021, Makale Kabul Tarihi: 12.12.2021 


\section{Giriş}

Evlilik birliğinin korunması, kanunda düzenlenen hallerde hâkimin müdahalesini de gerektirmektedir ve bu yönde verilen kararlar zaman zaman üçüncü kişileri etkileyebilmektedir. Türk Medeni Kanunu'nun 198. maddesinde düzenlenen birliğin giderlerine katılma yükümlülügünü yerine getirmeyen eşin borçlularına ödemenin diğer eşe yapılmasının emredilmesi, iş ilişkisinin sürekli niteliği ve işverenin borçlarının ağılıkla para borcu olması dikkate alındığında iş ilişkileri ve işçilik alacakları ile yakından ilgilidir. Yine işçi ücretinin korunması ile evlilik birliğinin korunması, birliğin giderlerinin karşılanabilmesi bağlamında bu müesseseler arasında irtibat bulunmaktadir.

Aile hayatından kaynaklanan sorunlara üçüncü kişilerin dahil edilmesine uygulamada mümkün mertebe son çare olarak başvurulma eğilimi gözlense de, inceleme konumuz olan eşin borçlularına emir verilmesi tedbirinin etkin çözüm yollarından biri olduğu göz önünde tutulmalıdır. Elbette menfaatler dengesi de gözetilmelidir.

$\mathrm{Bu}$ çalışmada eşin borçlularına ödemeyi diğer eşe yapmalarının emredilmesinin hukukî niteliği, iş ilişkisi üzerindeki etkileri, emir kapsamında yer alabilecek işçilik alacakları, iş sözleşmesinin tarafi işveren başta olmak üzere emrin muhatapları açıklanacak, konunun yargılama hukukuna ilişkin yönleri de ayrıca ele alınmaya çalışılacaktır.

\section{Genel Olarak Evlilik Birliğinin Korunması}

Eşler arasında evlenme ile evlilik birliği kurulmuş olur ve eşler bu birliğin mutluluğunu elbirliğiyle sağlamakla yükümlüdür (TMK m. 185). Türk Medeni Kanunu’na göre birliği beraberce yöneten eşlerin birbirine yardımcı olmaları, evlilik birliğinin giderlerine güçleri oranında emek ve malvarlıklarılla katılmaları gerekmektedir (m. 185, 186). Çocuklu aileler bakımından çocuğun gelişimi için gerekli yaşam şartlarının sağlanması, olanakları ve malî güçleri çerçevesinde öncelikle çocuğun ana-babasına düşen bir sorumluluktur ve bu sorumluluğun yerine getirilmesi ile ilgili harcamalar da birliğin başlıca giderleri arasındadır. 20.11.1989 tarihinde kabul edilen BM Çocuk Haklarına Dair Sözleşme'de de anılan sorumluluğa işaret edilmektedir (m. 27/2) ve sözleşmeye taraf devletlerin önlem alma yükümlülüğü bulunmaktadır². Taraf devletler, ulusal durumlarına göre ve olanakları ölçüsünde, ana babaya ve çocuğun bakımını üstlenen diğer kişilere, çocuğun bu hakkının uygulanmasında yardımcı olmak amaciyla gerekli önlemleri alırlar; anababası veya çocuğa karşı mali sorumluluğu bulunan diğer kişiler tarafindan, çocuğun bakım giderlerinin karşılanmasını sağlamak amacıyla her türlü uygun önlemi alırlar (m.27/3, 4).

2 Örneğin taraf devletler, çocuğun ana-babasınn, vasilerinin ya da kendisinden bukuken sorumlu olan diğer kişilerin hak ve ödevlerini de göz önünde tutarak, esenliği için gerekli bakım ve korumayn sağlamayn üstlenirler ve bu amaçla tüm uygun yasal ve idari önlemleri alirlar (m. 3/2). 
Eski Medeni Kanun'da yer alan evin reisinin koca olduğuna dair hükmün kaldırılmasına paralel olarak her iki eş de birliğin giderlerine katılmak zorundadır. Elbette bu yükümlülük eşit ölçüde, miktarda olmayıp eşlerin güçleri oranında emek ve malvarlıklarıla sağlayacakları katkıyı ifade etmektedir. Düzenleme Kanun'un özünde yatan eşitlikçi düşünce ile evlenen bireylerin bir hayat ortaklığ1 oluşturdukları gerçeğine uygundur. Eşlerin birbirine ve evlilik birliğine karşı sorumlulukları arttırlıp dengelenmek suretiyle evlilikteki birlik, kadın erkek eşitliği düşüncesi desteklenmektedir (Ayan, 2004: 54-55; Knoepfler, 1988: 122 vd.; Koçhisarlıŏlu, 1991: 432).

Evlilik birliğinin korunması Türk Medeni Kanunu'nda sadece eşlerin sorumluluk duyguları ve dayanışma anlayışlarına terk edilmemiş, gerektiğinde hâkimin müdahalesine de başvurulabileceği açıkça benimsenmiştir ${ }^{3}$. 195. maddeye göre, "evlilik birliğinden doğan yükümlülüklerin yerine getirilmemesi veya evlilik birliğine ilişkin önemli bir konuda uyuşmazlığa düşülmesi halinde, eşler ayrı ayrı veya birlikte hâkimin müdahalesini isteyebilirler" (f. 1). O halde hâkimin müdahalesinin şartlan;

a) Eşin veya her iki eşin evlilik birliğinden doğan yükümlülüklerini yerine getirmemesi veya

b) Eşlerin evlilik birliğine ilişkin önemli bir konuda anlaşamamaları,

c) Eşlerin birinin veya her ikisinin hâkimden müdahale talebinde bulunmalarıdır.

Böyle bir talep halinde hâkim, eşleri yükümlülükleri konusunda uyarma, uzlaştırmaya çalışma ve (eşlerin ortak rızasıyla) uzman yardımına başvurma gibi araçlardan yararlanabileceği gibi, gerektiği takdirde eşlerden birinin istemi üzerine kanunda öngörülen diğer önlemleri de alabilecektir (m. 195/f. 2, 3). Hâkim, talep şartıyla, ancak kanunda sinırlı şekilde sayılan önlemlerden birini alabilir (Kahveci, 2007: 276).

$\mathrm{Bu}$ önlemler öncelikle eşlerin birlikte yaşayıp yaşamamalarına göre ikili bir ayrımla düzenlenmiştir. TMK 196. madde uyarınca eşler birlikte yaşarken, eşlerden birinin istemi üzerine hâkim, ailenin geçimi için her birinin yapacağı parasal katkıyı takdir yetkisini kullanarak belirleyecektir (f. 1). Talebi aşmamak kaydıyla geçmiş 1 yıl ve gelecek yıllar için yapılacak bu belirlemede, somut olayın özelliklerine göre eşin ev işlerini görmesi, çocuklara bakması ve diğer eşin işinde karşılıksız çalışması dikkate alınacaktır. Yasada öngörülen şartların oluşması halinde eşlerden birinin ayrı yaşama hakkı da bulunmaktadır (m. 197). Birlikte yaşamaya ara verilmesi diğer eşi parasal katkıda bulunma yükümlülüğünden kurtarmadığından, hâkim yine

3 Kanun'un 195 ila 201. maddelerinde sayllan önlemlere "dar anlamda önlem" denilmektedir. $\mathrm{Bu}$ maddeler dışında kalmakla birlikte, çeşitli düzenlemelerde yer alan (taraflardan birinin talebi üzerine mal ayrllığına karar verilmesi, eşlerden birinin birliği temsil yetkisinin sınırlanması veya kaldırılması gibi) diğer önlemler ise "geniş anlamda önlem" kavramıla anılmaktadır (Bkz.; Öztan, 2015: 342). 
eşlerden birinin istemi üzerine birinin diğerine yapacağı parasal katkıya, konut ve ev eşyasından yararlanmaya ve eşlerin mallarının yönetimine ilişkin önlemleri alacaktır.

Kanunda öngörülen bir diğer tedbir eşin tasarruf yetkisinin kısıtlanmasıdır (TMK m. 199). Bu yetkinin sınırlanmasında ölçüt, ailenin ekonomik varlı̆̆ının korunması ile evlilik birliğinden doğan malî bir yükümlülüğünün yerine getirilmesindeki gereklerdir. Tasarruf yetkisinin sinırlanması neticesinde, sınırlanan eş bazı malvarlığı değerleri üzerindeki tasarruf işlemlerini (satış, bağışlama gibi) tek başına değil, ancak diğer eşin rızası halinde gerçekleştirebilecektir. Fakat bu sınırlama adeta bütünüyle fiil ehliyetine ve/veya eşin tüm malvarlığına yönelik olmayıp, hâkimin belirleyeceği malvarlı̆̆ değerlerine münhasırdır (f. 1)4. Fiil ehliyeti bakımından kısıtllilı ise, Türk Medeni Kanunu'nda vesayeti gerektiren haller arasında özel olarak düzenlenmiş ve ayrı bir prosedürü olan, sulh hukuk mahkemesince vasi tayinini gerektiren farklı bir müessesedir (m. $405 \mathrm{vd}$.).

İnceleme konumuzu asıl ilgilendiren önlem, Türk Medeni Kanunu’nun 198. maddesinde yer almaktadır. Hükme göre; "esslerden biri, birliğin giderlerine katulma yükü̈mlülï̈̆̈unü yerine getirmesse, hâkim onun borclularna ödemeyi tamamen veya kısmen diğer eşe yapmalarm emredebilir". Konunun aile içinde ekonomik şiddet ile ilgili yönü de bulunmaktadır. Bilindiği gibi şiddet fizikî saldırganlıktan ibaret değildir. Paranın, ekonomik kaynakların bir yaptırım, bask1, sindirme ve kontrol etme amaciyla kullanılması olarak tanımlanabilecek ekonomik şiddet, evlilik birliği içinde örneğin kadının maaşına, banka kartına el koyma gibi fiillerle veya eşin/kocanın eve yeterli para bırakmaması, gelirin nerede tutulduğu hakkında diğer eşe bilgi vermemesi ya da eksik bilgi vermesi şeklinde de kendisini göstermektedir (İnci, 2019: 191-192). Kanımızca Kanun'un 198. maddesi, aile içinde ekonomik şiddetle mücadelede de etkin bir araç işlevi görebilir. Aşağıda bu düzenleme, özellikle iş ilişkisi zemininde ele alınmaya çalısılacaktır. ${ }^{5}$

\section{Eşin Borçlularına Emir Verilmesi}

İsviçre Medeni Kanunu'ndan (ZGB Art. 177) alınan bu hüküm, yukarıda da değinildiği üzere Türk Medeni Kanunu'nun 198. maddesinde düzenlenmiştir. Borçlulara ait önlemler, evlilik birliğinin korunmasında hâkimin müdahalesini gerektiren haller bakımından eşlerin "evlilik birliğine ilişkin önemli bir konuda uyuşmazlığa düşmeleri” değil, "evlilik birliğinden doğan yükümlülüklerinin yerine getirilmemesi" ile ilgilidir. Bu bağlamda eşlerden birinin birlï̆gn giderlerine katılma yükkümlïlï̈̆̈̈ne aykırılığı esas alınmaktadır.

\footnotetext{
4 Sinırlamanın tasarruf yetkisi sınırlaması olmayıp, fiil ehliyetinin sınırlandığı görüşü için bkz:; Y1lmaz ve Bayramoğlu, 2016: 3147-3148.

${ }^{5}$ Doktrinde birliğin giderlerine katılma yükümlülüğünü yerine getirmeyen eşi ifade etmek üzere "bakım borçlusu, yükkümlüsü"; "yükeümlü eş" gibi kavramlar kullanılmaktadır (Bkz.; Gümüş, 2008: 181 vd.). Kısaca ifadeye elverişli örneklenen kavramlar bu çalışmada da zaman zaman kullanılabilecektir.
} 
Benzer düzenleme, eski Medeni Kanun'un 163. maddesinde "koca aile varifelerini ihmal ederse kar kocanm mallarm idare bususunda kabul ettikleri usul ne olursa olsun hakim, kar ve kocanm borçlularna borçlarmm tamamm veya bir kismm karrya ödemelerini emreder" şeklinde yer almakta idi. Görüldügü gibi eski kanunda sadece, kocanın yükümlülüklerini ihlal etmesi ve borçluların ifayı kadına yapması esas alınmış iken, yeni Medeni Kanun'da 198. madde ve diğer ilgili düzenlemeler cinsiyet temelli bir ayrım içermemekte, evlenme akdinin tarafı kadın veya erkek fark1 olmaksızın "eş" kavramından hareket etmektedir. Eski 163. maddenin yürürlügü döneminde hükmün kadın hakkında da kıyasen uygulanabileceği görüşü ileri sürülmüştür (Velidedeoğlu, 1960: 109).

Birliğin giderlerine her eşin ne şekilde ve kapsamda katk1 sağlayacağ1 hususunda eşlerin anlaşmaları esas olup, bu konuda örtülü irade açılamalarıyla anlaşma da mümkündür (Gürpınar, 2013: 1309; Koçhisarlıŏlu, 1991: 438). Giderlere katılma sadece malvarlığı değerleriyle katılımdan ibaret olmayıp, yukarıda belirtildiği gibi eşler birliğin giderlerine güçleri oranında malvarlıklarının yanı sıra emek ile de katılabilirler. Böylelikle aile birliği yapacağı bir harcamadan kurtulmakta, bir diğer ifadeyle pasifin artması ve aktifin azalması önlenmiş olmaktadır. Örneğin çocukların bakımını üstlenen eş, bakıcıya; yemek-temizlik gibi günlük hayatın temel ihtiyaçlarını karşılayan eş, ev hizmetlerinde çalıştırılacak bir kimseye yapılacak ödemeden ve bu giderlerden sakınmayı sağlamaktadır. Tabiatıyla, evlilik birliğinin giderleri için para kazanan, aktifi arttıran eş kadar emeğiyle katkı sağlayan eş de birliğin giderlerine katılmış olmaktadır.

Buna mukabil Türk Medeni Kanunu'nun 196. maddesindeki “...hakim, ailenin geçimi için her birinin yapacağı parasal katkayı belirler” hükmü, eşlerin birliğe emekleriyle yaptığı katkı ile ilgili değildir (Gürpınar, 2013: 1312-1313). Malvarlığının kapsamına giren çeşitli değerlerden sadece ailenin geçimi için gerekli belirli bir parayı esas almaktadır. Borçlulara ait önlemler başlıklı 198. madde de bu doğrultuda getirilmiştir. "Ödemenin" diğer eşe yapılmasını öngören düzenleme "para borçlarının" ifasına yöneliktir. Bunun kaynağı önemli olmayıp, para borcunun (eş bakımından alacağın) kanundan, sözleşmeden, haksız fiilden veya sebepsiz zenginleşmeden doğması bakımından fark bulunmamaktadır. Arızî (ani) veya ücret, kira gibi dönemsel para borçlarının ödenmesine karar verilebileceği gibi, kıymetli evraka bağlı alacağın ödenmesi de emredilebilir (Güven, 1998: 12; Uzun Birinci, 2016: 3741).

Manevî tazminat gibi şahsa bağlı alacaklarda ise ödeme emri verilemeyeceği kabul edilmektedir (Hausheer ve diğerleri, 1999: 604 N. 12b; Öztan, 2015: 375; Gümüş, 2008: 184; Gençcan, 2019: 410). Üçüncü kişi borçlunun, birliğin giderlerine katılma yükümlülügünü yerine getirmeyen eşe bir şahsî edim, menfî edim yahut mal teslimini üstlenmiş olduğu hallerde kendisine 198. madde uyarınca 
emir verilmesi ve ifanın diğer eşe yapılması söz konusu değildir ${ }^{6}$. Borçlu ile birliğin giderlerine katılma yükümlülügünü yerine getirmeyen eş arasındaki hukukî ilişkide alacaklının kişiliğinin önem taşıdığı yahut ifa yerinin münhasıran belirlendiği hallerde de 198. maddenin uygulanmasından sakınmak gereklidir. Örneğin birliğin giderlerine katılmayan kadının yazlığında temizlik işlerini gören bir kadın yardımcının, 198. maddeden bahisle temizlik işini kocanın yaşadığı kışlık konutta ifa etmesinin emredilemeyeceği kanaatindeyiz. Evlilik birliğinin korunmasına yönelik tedbir, 3. kişilerin taraf olduğu akdî ilişkilere gelişigüzel müdahaleye elverişli olmadığı gibi, bu kişilerin durumunu güçleştirmemeli, yeni ve başkaca sorunlara yol açmamalıdır. Uygulamada bu yönteme son çare olarak başvurulması ve aile ilişkilerine olabildiğince üçüncü kişilerin dahil edilmesinden kaçınılması gerektiği ileri sürülmektedir (Soyer, 2018: 77).

Değinilen açıklamalarla bağlantılı olarak ifade edilmelidir ki; kanımızca eşlerin üçüncü kişiden müteselsil alacaklı (TBK m. 169) oldukları hallerde de hâkim ödemenin diğer eşe yapılmasını emredebilir. Böylece müteselsil alacaklılıkta alacaklılardan her birinin ödemeyi talep edebilme yetkisi sona ermekte, o dönemle ve miktarla sınırlı olmak üzere alacaklılar arasındaki teselsül ilişkisi ortadan kalkmaktadır. Müteselsil alacaklılık, birliğin giderlerine katılma yükümlülügünü yerine getirmeyen eşin alacaklı, karşısındaki üçüncü kişinin ise borçlu sıfatını etkisizleştirmemektedir. Kanun ödemenin diğer eşe yapılmasını, para borcunun artık ona ifa edilmesini gözettiğinden 198. madde bu sonucu sağlamaya elverişli şekilde yorumlanabilir. Eşlerin müteselsilen alacaklı oldukları hallerde borcun kadına veya kocaya ödenmesi ihtimalinin varlı̆̆1 tartışmasızdır; ancak 198. madde sayesinde hiç değilse ödemenin müteselsil alacaklılardan birliğin giderlerine katılmayan eş yerine diğer eşe yapılması sağlanabilecektir.

Diğer yandan dikkat edilmesi gereken husus, 198. maddenin bir müteselsil alacaklılık hali öngörmediğidir. Düzenleme alacaklı eşin yanında diğer eşi de alacaklı kılmamaktadır ve borçlunun eşlerden herhangi birine yapacağı ödemeyle borçtan kurtulması mümkün değildir. Ödemenin, birliğin giderlerine katılmayan kişinin lehine ödeme emri verilen eşine yapılması gerekmektedir. Aksi takdirde bu eşe yeniden ifada bulunma zorunluluğu doğacaktır (Schwander, 2014: 1068 N. 2; Ayan, 2004: 256).

Borçlulara yönelik emir, eşin birliğin giderlerine katılma borcuyla sınırlı olup, eşler arasında başkaca bir alacağın tahsili amacıyla 198. madde işletilememektedir (Yllmaz, 2016: 257).

$\mathrm{Bu}$ önlem sadece birlikte yaşamaya ara verilmesi halinde alınmamaktadır. Sırf birlikte yaşamaya ara verilmesi halinde alınabilecek önlemler ayrı bir başlık altında

6 Benzer şekilde, üçüncü kişiler tarafından söz konusu eş lehinde bir aynî hakkın kurulmasına yönelik bir borcun ifasında da bu önleme başvurulamaz (Ayan, 2004: 254). Lafzî yorumdan kaçınarak "ödeme" ifadesine bağlı kalınmaması gerektiği, diğer maddî edimlerin ve hatta ev işlerinin görülmesine yönelik hizmet edimlerinin dahi diğer eşe ifasına hükmedilebileceği yolunda katılmadığımız görüş için bkz.; Gümüş, 2008: s. 185. 
197. maddede düzenlenmiştir. 198. madde gereğince borçlulara emir verilmesi ise, genel olarak birliğin korunması kapsamında gerek eşlerin birlikte yaşaması gerekse birlikte yaşamaya ara verilmesi halinde söz konusu olabilecektir (Göksu ve Heberlein, 2016: 577 N. 1; Öztan, 2015: 375; Ayan, 2004: 253 vd.; Samat, 2010: 9091). O itibarla Yargitay'in “davacmmn kira gelirleriyle ilgili talebi, Türk. Medeni Kanunu'nun 198. maddesine dayanmaktadrr...Ancak bu tedbir davacmon ayn yaşama süresince geçerli olur...Aģılanan yasal düzenleme dik.kate alnmadan evlilik süresince kira gelirlerinin davacı kadina öde(n)mesine karar verilmesi doğru görülmemiştir" şeklindeki içtihadına katılmamaktayız. Birliğin giderlerine katılma sadece eşler ayrı yaşarken doğan bir yükümlülük değildir. $\mathrm{Bu}$ yükümlülük eşler birlikte yaşarken evleviyetle yerine getirilmelidir. TMK 198. maddenin öngördüğü başlica şart, eşlerden birinin birliğin giderlerine katılma yükümlülügünü yerine getirmemesidir. Söz konusu yükümlülük evlilik birliği esnasında eşler birlikte yaşarken de ihlal edilebileceğine göre, Yargıtay'ın anılan kararı giderlere katılma yükümlülügünün niteliğine de uygun düşmemektedir. ${ }^{8}$ Eski Medeni Kanun döneminde Yargitay 2. Hukuk Dairesi 23.01.1979 T., 1978/9239 E., 1979/364 K. sayılı içtihadında ise bu tedbirin ancak ortak hayatın devam etmesi ve eşin savurganlık, kötü idare, içkiye düşkünlük gibi nedenlerle kısıtlanmasını gerektirecek durumların bulunması halinde alınabileceği görüşünü benimsemiştir?.

Esasen, birliğin giderlerine katılmayan eşin kusur durumu söz konusu önleme başvurulabilmesi için belirleyici değildir (Kahveci, 2007: 276; Hausheer ve diğerleri, 1999: 596 N. 8). Eş örneğin savurganlık, cimrilik nedeniyle yahut diğer eşi kendince cezalandırma niyeti ile giderlere katılmıyor olabileceği gibi, akıl hastalı̆̆na tutulmuş olması nedeniyle de katılma yükümlüğünü yerine getiremiyor olabilir. Ancak eşin yoğun bakımda olması, zorunluluk sebebiyle geçici olarak yükümlülüğün yerine getirilememesi halinde veya ihlal belirli bir ağırllk taşımıyorken hemen bu önleme başvurulmaması gerekir. (Gençcan, 2019: 404; Gümüş, 2008: 182; İnan Günay, 2018: 93; Uzun Birinci, 2016: 3740) .

Borçlulara ödemeyi diğer eşe yapmalarının emredilmesi için eşler arasında uygulanan mal rejiminin hangisi olduğu önem taşımamaktadır (Schwander, 2014: 1070 N. 9; Tekinay, 1984: 358; Gençcan, 2019: 408).

Talepte bulunan eşin (örneğin kadının) çalışması, gelir elde ediyor olması diğer eşin (kocanın) elektrik, su, telefon, kira, yakıt parası vb. giderlere katılma

$\begin{array}{llllllll}\text { Yarg1tay 2. HD. } \quad 17.02 .2010 & \text { T., } & 2009 / 22118 & \text { E., } 2010 / 2791 & \text { K. }\end{array}$ (http://www.kazanci.com/kho2/ibb/giris.htm Erişim tarihi:17.02.2020). Karar incelemesi için bkz.; Uzun Birinci, 2016: 3727 vd.

8 Yargitay 3.Hukuk Dairesi'nin 18.10.2007 T., 2007/14193 E., 2007/14996 K. sayll içtihadında ise hakimin anılan hüküm uyarınca koşulları gerçekleştiği takdirde, eşlerin birlikte yahut ayrı yaşaması halinde bu önlemi alabileceği vurgulanmıştır. (lexpera.com.tr Erişim tarihi: 04.12.2021).

9 ABD, 1979: 74. İçtihat, düzenlemenin uygulamasını zorlaştırdığı ve kanunun amacını açıça aştı̆̆ gerekçesiyle doktrinde eleştirilmiştir (Tekinay, 1984: 358). 
yükümlülüğünü tamamen ortadan kaldırmamaktadır. İçtihatlarda vurgulandığı üzere bu durum ancak miktarın takdirinde etkili olabilir ${ }^{10}$.

\section{Düzenlemenin Hukukî Niteliği}

İncelediğimiz konuda, borç ilişkisi (iş sözleşmesi) işçi ile işveren arasında ise de, sözleşmenin tarafı olmayan bir üçüncü kişinin (alacaklı işçinin eşinin) bu ilişkiden kaynaklanan bir alacağı talep edebilme yetkisi elde ettiği görülmektedir. Burada alacaklı işçinin herhangi bir iradesi, alacağı devir (temlik) kastı bulunmamaktadır ve zaten bu husustaki iradesi önem taşımamaktadır. O itibarla meselenin TBK 183. maddede düzenlenen alacă̆ın iradî devri ${ }^{11}$ ile ilgisi bulunmamaktadır. Alacak, kanunun açık bir düzenlemesiyle de başka bir kişiye geçmemektedir. Yasal devirde (kanunî temlik), alacak kanunda öngörülen belirli bir olayın gerçekleşmesi üzerine, alacaklının irade beyanı olmaksızın kendiliğinden üçüncü kişiye geçmektedir (Eren, 2017: 1253-1254). TBK 168. maddeye göre diğerlerine rücu hakkına sahip müteselsil borçlunun ifa ettiği tutar için alacaklıya halef olması ya da TMK m. 599'da düzenlendiği üzere mirasbırakanın ölümü ile mirasçıların mirası bir bütün olarak kanun gereğince kazanmaları (f. 1) yasal devire örnek gösterilebilir.

Alacağın devrinin bir diğger türü ise yargisal devirdir (kazaî temlik). TBK madde 185, "alacă̆n devri kanun veya mahkeme karar gereğince gerçekleşmişse, bu devir öz̧el bir şekle ve önceki alacaklının maasın açılamasına gerek olmaksızın, ücüncü kişilere karşı ileri sürülebilir" diyerek yasal devir ile yargisal devre işaret etmektedir. Alacağın mahkeme kararıyla alacaklının malvarlığından çıkarılıp başkasının mal varlığına dahil edilmesi alacağın yargisal devridir (Erdoğan, 1991: 484). TMK 198. maddeye göre alacaklı eşin borçlularına ödemenin diğer eşe yapılması hususunda bir mahkeme kararının bulunması nedeniyle olsa gerek, doktrinde 198. maddenin uygulanmasının bir kazaî temlik olduğunu ileri süren görüşler bulunmaktadır (Ayan, 2004: 256; Tekinay ve diğerleri, 1993: 265-266; Kılıçoğlu, 2010: 654-655; Zevkliler ve diğgerleri, 2013: 392; Dayınlarlı, 2010: 126; Yılmaz Kılıçoğlu, 2015: 442). Öte yandan, düzenlemeyi kazaî temlik örneği olarak zikreden görüşler arasında dahi, ifa ile borcun sona ermesi ve "üçüncü şahsa yapılan" ifa konusuna gelindiğinde Medeni Kanun'un aynı maddesi bu kez, -alacaklı veya onun temsilcisi olmayan üçücü bir şahsa yapılan ifa- şeklinde nitelenmektedir (Bkz. Tekinay ve diğerleri, 1993: s. 770-771; Zevkliler ve diğerleri, 2013: 296). Oysa 198. madde üzerinden alacağın temlik edildiği sonucu benimseniyor ise, artık diğer eşin alacaklı olmayıp üçüncü bir şahıs olduğundan söz edilmemesi gerekir idi. Reisoğlu da, TMK 198. maddeyi örneklediği açıklamalarında "Borçlu borcunu kural olarak alacakliya veya onun yetkili temsilcisine ifa etmeye mecbur olmakla birlikte, yasada öngörülen istisnâ̂ hallerde, borcun

10 Yarg1tay 3. HD. 15.01.2015 T., 2014/13710 E., 2015/754 K. (lexpera.com.tr Erişim tarihi: 17.02.2020).

11 İradî devir; kanun, sözleşme veya işin niteliği engel olmadıkça alacaklının, borçlunun rızası aranmaksızın alacağını üçüncü bir kişiye devredebilmesidir. 
üçücü bir şabsa ifası zorunluluğu vardır. Bu gibi özel durumlarda, alacakliya ifa borçluyu borcundan kurtarmaz” (2014: 298) diyerek, alacaklı sifatınin giderlere katilma yükümlülüğünü yerine getirmeyen eşte olduğunu, borcun kendisine ifa edilmesi gereken diğer eşin ise üçüncü şahıs konumunda yer aldığını ifade etmektedir.

Kanunun “önlem” olarak getirdiği söz konusu düzenlemeler geçici hukukî korumalar ile yakından ilgilidir. 6100 sayılı Hukuk Muhakemeleri Kanunu'nun 389 ila 406. maddeleri arasında başta ihtiyatî tedbir olmak üzere geçici hukukî korumalar düzenlenmiş, diğer kanunlarda geçici hukukî korumalara ilişkin yer alan Özel hükümler saklı tutulmuştur (m. 406 /2). Türk Medeni Kanunu, Türk Ticaret Kanunu, Fikir ve Sanat Eserleri Kanunu, İcra ve İflas Kanunu gibi birçok farklı yasada bu tür tedbirlere yer verilmiştir. 198. maddeyi de kapsayan evlilik birliğinin korunmasina ilişkin önlemler geçici mahiyettedir ve 200. maddede açıkça hâkimin koşullar değiştiğinde istem üzerine kararında gerekli değişikliği yapacağ1 veya sebebi sona ermişse alınan önlemi kaldıracağı düzenlenmiştir. ${ }^{12}$ Ancak HMK 389 vd. maddelerinde düzenlenen geçici hukukî korumalar arasında başlıca yer alan ihtiyatî tedbir kararı "uyuşmazlık konusu” hakkında verilebilecek iken"13, TMK 198. madde giderlere katılma yükümlülüğünü yerine getirmeyen eşin üçüncü kişideki alacağ1 hakkındadır. İhtiyatî tedbirler bakımından tamamlayıcı işlem şartı bulunmaktadır ve ihtiyatî tedbir dosyası asıl dava dosyasının eki say1lır. HMK 397. maddenin 1. fikrasına göre ihtiyatî tedbir kararı dava açılmasından önce verildiğinde, tedbir talep edenin, bu kararın uygulanmasını talep ettiği tarihten itibaren iki hafta içinde esas hakkındaki davasını açmak, dava açtığına ilişkin evrakı, kararı uygulayan memura ibrazla dosyaya koydurtmak ve karşıllğında bir belge almak zorunluğu bulunmakta iken (aksi halde tedbir kendiliğinden kalkar), incelediğimiz 198. madde bakımından örneğin bir boşanma davası açmak şart değildir. Evlilik birliğinin korunması önlemleri bağımsız karakterli olup, asıl yargılamaya bağlanmamıştır (Sungurtekin Özkan, 2003: 85; Erişir, 2013: 281; İnan Günay, 2018: 36-37). Düzenleme "birliğin korunması" başlığı altında yer aldığına göre, bu önlemlere başvurulabilmesi için evliliğin devam etmesi şarttır ${ }^{14}$.

TMK 196. maddenin 1. fikrası uyarınca eşin ailenin geçimi için yapacağ1 parasal katkının hâkim tarafindan belirlenmesi üzerine diğer eşin bu tutarda alacak

12 Doktrinde bu düzenlemeler "geçici önlem", "geçici tedbir" ya da "aile bukukuna özgü geçici önlem” kavramlarıyla ifade edilmektedir. (Bkz. Erişir, 2013: 234; Kuru, 2001: 4290, 4309). Akkan'a göre de Medeni Kanun'da yer verilen bu tedbirler aile hukukuna dair geçici hukukî korumalardir (2007: 62).

13 "Hukuk. Mubakemeleri Kanununa göre sadece uyusmazlık konusu bakkinda tedbir karar verilebilir. Davacmm... bosanmaya karar verilmesi halinde bükmedilmesi mümkün olan tazminat ve nafaka haklarmm elde edilmesini temin için de olsa dava konusu olmayan kocanm taşımaz̧lar üzerine tedbir konulamaz:” Yargitay 2. HD. 22.10.2015 T., 2015/4062 E., 2015/19077 K. (lexpera.com.tr Erişim tarihi: 17.02.2020)

14 Yargitay 2. HD. 17.04.2019 T., 2019/1279 - 4862 (lexpera.com.tr Erişim tarihi: 17.02.2020) 
hakkı bulunmaktadır ve söz konusu belirleme bir tespit hükmünü işaret etmektedir. Ancak son fikraya göre bu katkılar, geçmiş bir ynl ve gelecek yullar için istenebileceğinden geçmiş bir yıllık döneme ilişkin katkı tutarı, davacı eş yönünden tahakkuk etmiş bir alacak hakkı mahiyetindedir ve aynı davada bir eda talebine konu edilebilir. Geçmiş bir yıl, elbette evlenme tarihinden öncesine gitmemek kaydıyla, dava tarihinden geriye doğru azamî bir yıllık süreyle sınırlıdır. Bilindiği gibi 4721 sayılı Türk Medeni Kanunu'nda eşler arasında cebrî icra yasağı bulunmamaktadır. Talepte bulunan eşin 196. madde vesilesiyle belirlenen tutardaki alacağının tahsili amacıyla diğer eşe karşı icra takibine girişmesi mümkündür. Böyle bir icra takibinde, borçlu eşin üçüncü kişilerdeki para ve alacakları İcra ve İflas Kanunu uyarınca haczedilebilecektir.

198. maddede uyarınca eşin borçlularına ödemeyi kısmen veya tamamen diğer eşe yapmalarının emredilmesi halinde ise, karardaki emrin muhatabı borçlu üçüncü kişi olup, lehine ödeme emri verilen eş bu alacağ doğrudan doğruya borçludan talep yetkisi elde etmektedir. Bilindiği gibi, alacağ1 talep yetkisi kural olarak o alacak hakkının sahibine aittir. Borçlu da ancak alacaklıya veya onun yetkili temsilcisine yapacağı ödeme/ifa ile borcundan kurtulabilir. Medeni Kanun'un 198. maddesinde esasen alacak hakkı sahibi, evlilik birliğinin giderlerine katılma yükümlülüğünü yerine getirmeyen eştir. Fakat kanunun tanıdığ1 imkân sayesinde artık diğer eş ifayı talep yetkisini elde etmektedir. Velidedeoğlu da, bu emir ile borçluya karşı takibe girişme ve dava açma yetkisinin artık doğrudan diğer eşe ait olduğunu, birliğin giderlerine katılma yükümlülüğünü yerine getirmeyen eşin söz konusu alacağının tahsil ve takibi yönünden sınırlı ehliyetli duruma düştügünü belirtmiştir (1960: 109-110) ${ }^{15}$.

Borcun alacaklıya ya da onun yetkili kıldığ bir şahsa ifa edilmesi kural olmakla birlikte, istisnaen kanun alacaklının rızası olmaksızın borcun bir üçüncü kişiye ifası imkânını tanımış hatta bunu zorunlu kılmış olabilir (Oğuzman, 1979: 1415). Alacaklının alacaklısına edada bulunma hukuk düzenine bütünüyle yabancı bir konu değildir (von Tuhr, 1983: 480-481). Esasen alacak ve talep birbirinden ayr1 kavramlardır. Kural olarak ifanın alacaklıya yapılması gerekir ve alacaklı edayı talep hakk1 olan kişidir (von Tuhr, 1983: 50). Alacak hakkının alacaklıya sağladığ1 en önemli yetki talep yetkisi ise de, bu iki kavram özellikle konuları, doğuş anları ve kapsamı yönünden birbirinden farklıdır. ${ }^{16}$ Talep hakkı yalnız alacaklardan değil aynî haklardan da doğabilmektedir. Keza vadeye bağlı borçlarda görüldüğü gibi alacaklı ile borçlu arasında bir alacak hakk1 mevcut olduğu halde bu alacaktan henüz bir talep hakkı doğmamış olabilir (Oğuzman, 1987: 8; Velidedeoğlu, 1948: 378 vd.).

Feyzroğh'nun ifade ettiği haliyle burada alacak hakk1 diğer eşe intikal etmez, sadece ifanın ona yapılması emredilmektedir (1977: 623). Oğurman üçüncü kişiden

15 Ancak eşin tasarruf yetkisinin sınırlanmasına dair özel bir hüküm içermeyen eski Medeni Kanun döneminde yazar, keza eşin bu alacak veya alacaklar üzerindeki tasarruf yetkisinin de sınırlandığını dile getirmektedir (Velidedeoğlu, 1960: 109-110). Benzer görüş, Akıntürk, 1967: 131 .

${ }^{16}$ Geniş bilgi için bkz.; Eren, 2017: 77 vd. 
alacaklı eşin evlilik birliğinden doğan yükümlülüklerini ihmal etmesi halinde borçluya ödemeyi diğer eşe yapmasının emredilmesini, ifanın "alacaklı dışında" "bir başkasına yapılması" hali olarak değerlendirmektedir (1979: 19-20). Atalay, bu maddede düzenlenen geçici hukukî koruma tedbirinin alacağın mahkeme kararıly devri anlamına gelmediğini, keza üçüncü kişilerdeki bir alacağın ihtiyaten haczedilmiş de olmadığını ifade etmektedir (2003: 60). Öđtan'a göre de, borçlulara karşı diğer eş alacaklı değil, tahsile yetkili kişidir. Alacaklı eş ise üçüncü şahıslara karşı alacaklı durumunu muhafaza eder; fakat alacağı talebe yetkili değildir. Karar hukukî niteliği itibariyle bir alacağın temliki değildir. Alacağı talep yetkisi hâkimin kararı üzerine diğer eşe geçmiştir (2015: 375-376. Aynı yönde Gümüş, 2008: 186; Y1lmaz, 2016: 250, 271; Gençcan, 2019: 419; İnan Günay, 2018: 94; Uzun Birinci, 2016: 3746; Göksu ve Heberlein, 2016: 578 N. 2; Schmid, 2016: 344 N. 7). Alacaklının, üçüncü şahsa ifayı talep yetkisi vermesi genellikle "iradî" olarak gerçekleşmekle birlikte, kanunla da düzenlenmesi mümkündür. Nitekim Akyol da Medeni Kanun’un incelediğimiz 198. maddesinin alacağın temlikini esas almadığını, üçüncü şahsın ifayı kendi adına talep yetkisinin kanunî olarak düzenlenmesine örnek olduğunu ifade etmektedir. Burada yetkiyi veren alacaklı değil, onun yerine bu yetkiyi kanundan alan hâkimdir. Üçüncü şahsa ifayı talep yetkisinin iradî olarak verilmesi borçlunun rızasını gerektirmediği gibi, bu hukukî durum 198. maddede olduğu gibi kanunî bir hükme dayandığında alacaklının da rızasına bağlı değildir (2007: 97).

Esasen kararın bir önlem, geçici mahiyette bir hukukî koruma olduğu göz önüne alındığında konunun alacağın yargısal devri niteliği taşımadığı açıktır. Kanımızca yargısal devir görüşü, TMK 200. madde uyarınca hâkimin kararında gerekli değişikliği yapabileceği veya önlemi kaldırabileceği olgusunu da göz ardı etmekte, böyle bir değişiklik veya kaldırma halinde alacağın tekrar ve bu kez kendiliğinden yükümlü eşe mi geçtiği sorusunu beraberinde getirmektedir. Alacağın devri, alacağın önceki alacaklıdan devralan alacaklının malvarlığına kesin olarak geçmesini sağlayan bir tasarruf işlemi olduğuna göre, soruya olumlu cevap vermek herhalde mümkün değildir ve zaten değişiklik yahut kaldırma kararında buna ilişkin bir yön de bulunmamaktadır. Alacaklı tarafın değiştiği hallerde alacağın devrinden söz edilebilir (Erdoğan, 1991: 480), oysa burada alacaklı kişi değişmemektedir.

Borcun alacaklı dışında üçüncü kişiye ifa edilmesi hakkında benzer bir düzenleme, İcra ve İflas Kanunu’nun 89. maddesinde borçlunun üçüncü kişilerdeki mal ve alacaklarının haczi ile ilgili olarak getirilmiştir ${ }^{17}$. Buna göre kısaca, icra memuru tarafindan (takip borçlusuna borçlu olan) üçüncü kişiye gönderilen haciz ihbarnamesinde, ihbarnamede gösterilen borca haciz konulduğu, üçüncü kişinin bu borcunu ancak icra dairesine ödeyebileceği, takip borçlusuna yapılan ödemenin geçerli olmayacağı... bildirilir. Üçüncü kişilerdeki mal ve alacakların haczinde, takip borçlusunun üçüncü kişiden olan alacağı, takibe girișen alacakliya devredilmemekte, fakat borç yasa gereği ona ifa edilmektedir. Zira düzenleme kendisine söz konusu

${ }^{17}$ Geniş bilgi için bkz.; Kuru, 2013: 459 vd.; Pekcanıtez ve diğerleri, 2008: 254 vd. 
alacağı doğrudan talep yetkisi tanımaktadır. (Akyol, 2007: 2; Zevkliler ve diğerleri, 2013: 296)

Yine İ́K 120. maddesinin 2. fikrasında, hacze iştirak edenlerin hepsi veya içlerinden birisinin borçlunun üçüncü bir șahıstaki alacağının tahsilini veya böyle bir șahsa karșı haiz olduğu dava hakkının kullanılmasını üzerlerine alabilecekleri düzenlenmektedir. Burada, takip borçlusu ile 3. kişi arasındaki borç ilişkisine taraf olmayan ve o ilişkide alacaklı sıfatı taşımayan bir kimseye kanundan doğan dava yetkinliği düzenlenmekte, takip alacaklısına kendisine yabancı bir hakkı kendi adına ileri sürme imkânı tanınmaktadır (Deren Yıldırım, 1996: 103-104). Bu durumda icra takibinin alacaklısı, borçlunun halefi olmayıp ortada alacağın temliki bulunmamaktadır. Alacaklıya, takip borçlusunun alacağ1-alacak hakkı değil, sadece bu hakka ilişkin dava takip yetkisi devredilmektedir (Deren Y1ldırım, 1996: 105; Kuru, 2013: 633; Üstündağ, 1995: 297; Pekcanıtez ve diğerleri, 2008: 312; İyilikli, 2011: 105). Konu, özellikle alacak hakk1/alacaklı sıfatı ile takip yetkisinin ayrıştırılabileceğini, üçüncü bir şahsın da ifayı kendi adına talep yetkisinin bulunabileceğini göstermesi bakımından önemlidir.

198. maddenin Türk Medeni Kanunu'nda düzenlendiği yere de bakıldığında, bunun evlilik birliğinin korunmasına yönelik bir geçici hukukî koruma tedbiri olduğu görülmektedir. Konu, birliğin korunması ile ilgili hükümler arasında borçlulara ait önlemler başlığ1 altında düzenlenmektedir. Verilen karar bir kesin hüküm teşkil etmemekte, koşullar değiştiğinde hakim talep üzerinde gerekli değişikliği yapabilmekte veya aldığı önlemi kaldırabilmektedir. Kararın bir mahkeme tarafindan verilmiş olması, bunun bir kazaî temlik olarak nitelenmesini gerektirmemektedir. Zaten geçici hukukî koruma tedbirleri hakkındaki kararlar, kural olarak yargı mercileri tarafindan verilmektedir (Y1lmaz, 2001: 35). Sonuç olarak, düzenlemenin bir kazaî temlik niteliği taşımadı̆̆1, aile hukukuna özgü geçici bir hukukî koruma tedbiri olduğu ve diğer eşe ifayı talep yetkisi sağladı̆̆ı görüşündeyiz ${ }^{18}$.

\section{İşçilik Alacaklarının Diğer Eşe Ödenmesi}

Türk Medeni Kanunu'nun 198. maddesinin uygulanmasında iş ilişkisinden doğan borç ve alacaklar büyük bir öneme sahiptir. İş sözleşmesi ile taraflar (işçi - işveren) arasında sürekli bir ilişki doğmaktadır. İşverenin aslî edim yükümü olan ücret ödeme borcu, dönemsel/devrî bir para borcudur ve bu niteliğiyle 198. madde ile yakından ilgilidir. Ücretin, işçinin hayatını idame ettirebilmesi ve ailenin geçimini sağlamadaki vazgeçilmez önemi dikkate alındı̆̆ında ücret alacağı iş mevzuatında özel olarak korunmaktadır. Medeni hukuk alanında da evlilik birliğinin korunması, giderlere katılmanın yerine getirilmesi bağlamında ve işçi olan eşin anılan yükümlülügünü yerine getirmemesi halinde, ücret ile diğer alacaklarının işverence diğer eşe (kısmen veya tamamen) ödenmesi, bu noktada her iki hukuk dalının korumayı amaçladıkları

18 Önceki Medeni Kanunu'nun 163. maddesinde yer alan benzer düzenlemenin de bir geçici hukukî himaye tedbiri olduğu hakkında bkz. Y1lmaz, 2001: 675, 679. 
alanlara hizmet etmekte ve adeta bir bütünlük teşkil etmektedir. Uygulamada talimatın yönlendirildiği borçluların çoğunluğunu ve en önemli kesimini işverenler oluşturmakta, hükmün en etkili uygulama alanı iş sözleşmesinden doğan alacaklarda ortaya çıkmaktadır (Velidedeoğlu, 1960: 109; Ayan, 2004: 254; Yılmaz, 2016: 264; Akıntürk ve Ateş, 2016: 141; Schwander, 2014: 1068 N.2).

Hemen belirtelim, iş hukukunda devir ve rehin yasağı (TBK m. 410, İş K. m. 35), işverenin işçiden olan alacağını ona olan borcuyla sınırlı takas imkânı (TBK m. 407) gibi koruyucu düzenlemeler "ücrete" ilişkindir (Süzek, 2018: 388-389; Çil, 2010: 718; Mollamahmutoğlu, 2005: 421). Medeni Kanun’un 198. maddesi ise sadece ücret alacaklarından ibaret olmayıp her türlü para alacağını, örneğin kıdemihbar tazminatlarını da ilgilendirmektedir.

\section{İşverenin Ücret ve Paraya Iliş̧kin Diğer Borçları}

Bir iş sözleşmesinde işverenin edimlerinin başında ücret ödeme yükümü gelmektedir. İş Kanunu'nun 8. maddesine göre iş sözleşmesi, bir tarafin (iş̧̧i) bağımlı olarak iş görmeyi, diğer taraf işverenin de ücret ödemeyi üstlenmesinden oluşan sözleşmedir. Ücret, çıplak/temel ücret olabileceği gibi ikramiye-prim-ilave tediye gibi ücret ekleri ile yol-yemek ücreti, yakacak-öğrenim yardımı vb. sosyal yardımları içeren giydirilmiş ücret de olabilecektir (Sümer, 2006: 72 vd.). Fakat bir işyerinde sosyal yardımlar nakden değil ayın cinsinden sağlanıyor, örneğin işgünleri için yemek ücreti ödenmeyip işyerinde işçilere yemek veriliyor ise bunların TMK $\mathrm{m}$. 198 kapsamında yer almadığı açıktır. Isşçinin fazla saatlerle çalışma yapması, hafta ve genel tatil günlerinde çalışması halinde ödenmesi gereken fazla çalışma, fazla sürelerle çalışma, hafta tatili çalışma ücreti ile ulusal bayram-genel tatil mesai ücretleri de işverenin nakden ödemesi gereken borçlarındandır. Isş̧inin alacakları kanundan, iş sözleşmesinden, toplu iş sözleşmesinden, işyeri uygulamasından veya işverenin genel vaatlerinden doğabilecektir.

İşçilik alacakları sırf iş sözleşmesinin yürürlüğüne münhasır olmayıp, işçinin akdin feshine bağlı kıdem, ihbar tazminatı, kötüniyet tazminatı, yıllık izin ücreti gibi alacakları da bulunabilecektir. Ayrıca İş Kanunu m. 18 uyarınca iş güvencesi kapsamındaki işçilerin iş sözleşmelerinin geçersiz feshinin malî sonuçları arasında yer alan işe başlatmama (iş güvencesi) tazminatı, boşta geçen dört aylı süreye ait ücret ve diğer parasal hakları (m. 21) da bu kapsamdadır. İşverenin eşit işlem yapma borcuna aykırı davranması halinde İş Kanunu'nun 5. maddesinde düzenlenen dört aya kadar ücret tutarında hükmedilecek tazminat ve yoksun bırakıldığı hakları, keza sendikal ayrımcılı̆̆ın ve sendikal nedenle feshin yaptırımı olan sendikal tazminat (6356 sK. m. 25) işçinin alacakları arasındadır. Kanunen işverene akit yapma yükümlülüğü getirilen örneğin İş Kanunu'nun 30. ve 31. maddelerine aykır1lık halinde öngörülen tazminatların ${ }^{19}$ da diğer eşe ödenmesine karar verilebilecektir.

19 İsyerinden malulen ayrılmak zorunda kalıp da maluliyeti ortadan kalkan işçilerin işe alınması yükümlülügüne aykırılığın bağlandığ1 altı aylık ücret tutarında tazminat; herhangi 
Sosyal sigorta primlerinden sorumluluk ise bu kapsamda görülmemelidir; zira prim borcunun alacaklısı işçi değildir. TBK m. 414 uyarınca, "issveren, işin görülmesinin gerektirdiüi her türlü harcama ile işsciyi işyeri dsşnda çallştrrdiğ takdirde, geçimi için zorunlu olan harcamalar da ödemekle yükkümlüdür" (f. 1). Genellikle uzun yol şoförleri, sahada çalışan tanıtım ve satış temsilcileri gibi işçiler yönünden masrafların karşılanmasında işçiye yapılan bu tür ödemeler esasen işçinin geliriyle ilgili olmayıp, maddede zikredildiği üzere işin görülmesinin gerektirdiği harcamalardır. Köprü, otoyol geçiş ücretleri, yakıt parası vb. nedenlerle işçiye yapılacak ödemelerin TMK 198. madde ile irtibatlandırılmaması ve bunlara ilişkin olarak işçiye ödeme yapıldığında, işverenin ödeme emrine aykırılığından söz edilmemesi gereklidir. Yine işçi, işyeri dışında çalışırıldığında yemek, konaklama giderlerine mahsuben ödemeler, bizzat işçinin yaşayışı için zorunlu olduğundan bunlara müdahale edilmemelidir.

Doktrinde yükümlü eşin muaccel alacağının bulunması şartı ileri sürülmüş (Gençcan, 2016: 723; Gençcan, 2019: 409; İnan Günay, 2018: 94)20 ise de, kanımızca, borçlulara ödemeyi diğer eşe yapmalarının emredilebilmesi için işçinin alacağının muaccel veya müeccel olması belirleyici değildir. Maddede ve gerekçesinde alacağın muacceliyeti şartına yer verilmemiş̧tir. Alacağın doğmuş olmas1, varllğ1 yahut sürekli bir hukukî ilişki kapsamında müstakbel bir alacak olmas1 gerekli ve yeterlidir ${ }^{21}$. 198. madde sadece borcunu vadesinde ödemeyen ve mütemerrid borçluları esas almamaktadır. Düzenlemenin amacı ve fiilî seyir bakımından değerlendirildiğinde de mahkemeye başvuru, dilekçelerin karşılıklı tebliği, cevap süresi, yargilama, kararın verilmesi ve borçluya tebliği gibi aşamalarla aradan geçecek sürede borcun zaten alacaklı eşin kendisine ödenmiş olması kuvvetle muhtemeldir. Mahkemeden talepte bulunabilmenin dahi eşin alacağının muaccel olması şartına bağlanması hükmün amacına hizmet etmemekte, aksine ondan uzaklaşmaktadır. 198. maddenin asıl etkin uygulaması müeccel alacaklar yönündendir. Yine, devrî/dönemsel edimler açısından aynı borçludan tek borç ilişkisi kapsamındaki her ödeme dönemine göre vadesi gelmiş alacak için usûl ekonomisine de aykırı şekilde ayrı ayrı çok sayıda başvuru zarureti doğurmanın pratik faydası ve hukukî bir dayanağı bulunmamaktadır. Hükmün en geniş uygulama alanı arasında yer alan ücret alacakları yönünden, İş K. 32. maddeye göre ücret en geç ayda bir ödenir, sözleşmelerle ödeme süresi bir haftaya kadar

bir askerî ve kanunî ödev dolayısıyla işinden ayrılan işçiler bakımından yasada öngörülen şartların varlı̆̆ halinde ödenmesi gereken üç aylık ücret tutarında tazminat alacağı gibi.

20 Öztan, hâkimin borçluyu seçerken borcu muaccel hale gelmiş ve miktar itibariyle daha fazla borcu olan borçluyu -tercih- edeceğini belirtmektedir (2015: 374). Buna karşllı yazar, "Borglulara talimat verme, kural olarak devamh tekrarlanan alacaklar içindir. Talimat daha çok ücret alacaklarna yöneliktir" tespitinde bulunmaktadır (Öztan, 2015: 377).

${ }^{21}$ Borç senede dayalı olursa hâkim borçlulara ileride süreleri dolacak olanları diğer eşe ödemelerini emredebilir (Şener, 1998: 778). İleriye yönelik olarak henüz muaccel olmamış periyodik gelirler de bu kapsamdadir (Yllmaz, 2016: 267). 
indirilebilir. Müeccel ve müstakbel alacakların kapsam dışı olduğu benimsenir ise, diğer eşin ödeme periyoduna göre örneğin her haftalık ücret için ayr1 talepte bulunup karar alması zorunluluğu doğar ki, böyle bir sonucun yukarıda belirtilen gerekçelerle benimsenemeyeceği görüşündeyiz. TMK.nın 200. maddesindeki

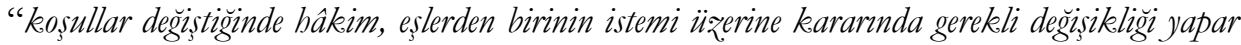
veya sebebi sona ermisse alnan önlemi kaldrnr" düzenlemesi de dikkate alındığında 198. maddenin muaccel alacakların yanı sıra müeccel alacaklar ile sürekli bir borç ilişkisinde dönemsel edimleri de kapsadığı anlaşılmaktadır. Bir kere muaccel hale gelmiş borç, ödeme emri doğrultusunda zaten davacı diğer eşe ödenmiş ise hâkimin artık bu hususta geleceğe matuf değiştireceği yahut kaldıracağ1 bir kararı olmadığ1 gibi, böyle bir talepte hukukî yarar da yoktur. Söz konusu önlemin (örneğin miktar yönünden) değiştirilmesi yahut kaldırılması bu madde doğrultusunda ancak müeccel ve/veya dönemsel diğer borçlar açısından anlam ifade edebilir.

Elbette ödeme emrinin verilmesi vadeyi öne çekmemekte, müeccel bir alacağ1 muaccel hale getirmemektedir. Ödeme emri, vade ne zaman ise ödemenin yine o tarihte yapılmasını, ancak başlangıçtaki alacaklı işçi yerine, borcun onun eşine ödenmesini esas almaktadır. Tebliğden önce işçiye yapılan ödemeler bakımından işverenin ayrıca eşe karşı herhangi bir ödeme yükümlülüğü bulunmamaktadır. İşverenin TMK m. 198 kapsamındaki sorumluluğu tebliğden itibaren başlamaktadır (Hausheer ve diğerleri, 1999: 603 N.11b). İş̧inin alacağ1 tebliğden önce doğmuş olsa bile, henüz borcun ödenmemiş olması halinde artık diğer eşe ifa edilmesi gerekmektedir. Hâkim koşullar değiştiğinde, eşlerden birinin istemi üzerine kararında gerekli değişikliği yapabilir veya sebebi sona ermiş ise alınan önlemi kaldırabilir ise de, bu yönde bir değişiklik, önleme son vermeye dair yeni bir karar olmadıkça işveren, ödeme emri çerçevesinde işçiye olan borcunu onun eşine ödemeyi sürdürmelidir.

\section{İş İlişkilerinde TMK m. 198 Bakımından Sorumlular}

Türk Medeni Kanunu'nun 198. maddesinin iş hukukundaki uygulaması bakımından ödeme emrinin muhatab1, öncelikle evlilik birliğinin giderlerine katılma yükümlülügünü yerine getirmeyen işçinin işverenidir. İşveren, gerçek veya tüzel kişi yahut tüzel kişiliği bulunmayan kurum ve kuruluşlar olabilir (İş K. m. 2). İşverenin kamu tüzel kişisi olması da mümkündür. İşçi bir alt işverenlik ilişkisi kapsamında alt işveren işçisi olarak çalışıyor ise, o işyeriyle ilgili alacaklarından asıl işveren de İş Kanunu'nun 2. maddesindeki düzenlemeye göre alt işveren ile birlikte sorumluluk taşıdığından asıl işverene de bu yönde emir verilebilmesi mümkündür. Ancak mükerrer ödemeye yol açılmamasına dikkat edilmelidir. Alt işverenlik ilişkisinden söz edebilmek için asıl işverenden üstlenilen işin ${ }^{22}$ münhasıran bu işte çalıştırılan alt

22 Alt işverene birakılabilecek işler, bir işverenin işyerinde yürüttüğü mal veya hizmet üretimine ilişkin yardımcı işler ya da asıl işin bir bölümünde işletmenin ve işin gereği ile teknolojik nedenlerle uzmanlık gerektiren işlerdir (İş K. m.2/6). 
işveren işçileri eliyle, asıl işverenin işyerinde yerine getirilmesi gerekir. İşi alanın üretimi kendi işyerinde yerine getirmesi halinde franchise ya da fason üretim söz konusu olacağından asıl işveren - alt işveren ilişkisi ve dolayısıyla asıl işveren sıfatıyla birlikte sorumluluk hali bulunmayacaktır (Eyrenci ve diğerleri, 2004: 31 Ekonomi, 2008: 33).

İş Kanunu m. 6 uyarınca işyerinin devri halinde, devir tarihinde işyerinde veya bir bölümünde mevcut olan iş sözleşmeleri bütün hak ve borçlarılyla birlikte devralana geçmektedir. İsyerinin veya bir bölümünün kira sözleşmesi gibi bir hukukî işleme dayalı olarak geçici yahut satım sözleşmesiyle sürekli ve kesin olarak devredilmesi mümkündür (Aktay ve diğerleri, 2007: 72). İşyeri devri iş sözleşmesinin sona ermesine yol açan bir sebep olmayıp, aksine İş Kanunu iş ilişkisinin devralan işverenle sürmesini esas aldığından, henüz bu aşamada kıdem tazminatı gibi sona ermeye bağlı alacaklara hak kazanılmamaktadır (Sümer, 2006: 25; Özkaraca, 2008: 359; Narmanlıŏlu, 2014: 153-155; Çil, 2020: 56-57)23. Buna karşıllk işçinin ücret, ikramiye gibi alacakları devir tarihinden önce doğmuş olsa bile, devralan işverene ödemeyi ilgili işçiye değil, onun eşine yapması emri verilebilecektir. Keza devreden işveren de, devirden önce doğmuş bulunan ve devir tarihinde ödenmesi gereken borçlardan iki yll süreyle birlikte sorumlu tutulmuştur (İş K. m. 6/ f. 3). Önceki işverenin, kıdem tazminatının işçiyi çalıştırdığı süre ve devir esnasındaki ücret seviyesine göre belirlenen kısmından birlikte sorumluluğunda ise iki yıllık sınır bulunmamaktadır (İş K. m. 120, 1475 sayılı İş K. m. 14). Bu sorumluluk esasları dahilinde devreden işverenin de TMK 198. madde doğrultusunda ödeme emrine muhatap olması gündeme gelebilecektir. Devirden önce sona ermiş iş sözleşmeleri bakımından ise, devralan işverenin TBK m. 202'ye göre bir malvarllğının ya da işletmenin aktif ve pasifleriyle devralınması hükümleri kapsamında sorumluluğu yoluna gidilebilecektir (Özkaraca, 2008: 342 vd.; Soyer, 2010: 38; Çil, 2020: 60).

Geçici iş ilişkisinde, geçici iş ilişkisi kurulan işveren de -İş Kanunu 7. maddedeki unsur ve şartlar çerçevesinde- ücret alacağı bakımından borçlu sıfatı taşıyabileceğinden ona da ödemeyi işçinin eşine yapması emredilebilecektir. Geçici iş ilişkisi özel istihdam bürosu aracıllŏgyla ya da holding bünyesi içinde veya aynı şirketler topluluğuna bağlı başka bir işyerinde görevlendirme yapılmak suretiyle iki ayr1 türde kurulabilmektedir (İş K. m. 7/f. 1). Yasal düzenlemeye göre; devir sırasında işçinin yazılı rızasının alınması şartıyla, işverenin bir işçisini holding bünyesinde veya aynı şirketler topluluğuna bağlı başka bir işyerinde iş görme edimini yerine getirmek üzere geçici olarak devretmesi halinde ortaya çıkan basit geçici iş ilişkisinde, işçisini geçici olarak devredenin işveren sıfatı ve iş sözleşmesinden kaynaklanan yükümlülükleri sürdügü gibi, geçici iş ilişkisi kurulan işveren de işçinin kendisinde çalıştı̆̆ sürede ödenmeyen ücretinden (ayrıca işçiyi

23 Türk Ticaret Kanunu'na göre birleşme, bölünme ve tür değiştirmenin iş akdinin yürürlüğ̈une etkisi hakkında geniş bilgi için bkz.; Alp, 2012: 51-74. 
gözetme borcundan ve sosyal sigorta primlerinden) birlikte sorumluluk taşımaktadır. Özel istihdam bürosu aracıllğıyla (meslek edinilmiş) geçici iş ilişkisi ise, Türkiye İş Kurumu'nca izin verilen özel istihdam bürosu ile geçici işçi çalıştıran işverenin "geçici işçi sağlama sözleșmesi" akdetmesine dayalı olarak ve ancak yasada sayılan hallerde (m.7/f. 1/a-f bentleri) kurulabilir. İş sözleşmesinin tarafi işveren ise özel istihdam bürosudur (Güzel ve Heper, 2017: 39-40)24. Bu tür geçici iş ilişkisinde geçici işçi çalışıran işverenin birlikte sorumluluğu oldukça sinırlı şekilde düzenlenmiştir. Onun sorumluluğu, İş Kanunu'nun 7. maddesinin 2-f bendi kapsamında ${ }^{25}$-işletmenin ortalama mal ve hizmet üretim kapasitesinin geçici iş ilişkisi kurulmasını gerektirecek ölçüde ve öngörülemeyen şekilde artması halindekurulan geçici iş ilişkilerinde ve işyerinde bir ayın üzerinde çalışan geçici işçilerin en çok üç aya kadar olan ücretleri yönündendir (Akyiğit, 2020: 155; Güzel ve Heper, 2017: 46). Geçici işçi çalıştıran işverene TMK m. 198 uyarınca ödeme emrinin de ancak bununla sınırlı olarak verilebileceği göz önünde tutulmalıdır. Geçici işçi çalıştıran işverenlerin sorumluluk taşılığ 1 ücretin, çıplak ücretin yanında ücret eklerini, fazla çalışma, hafta ve bayram tatili çalışma ücretlerini de içerir şekilde geniş yorumlanması benimsenmelidir (Çelik ve diğerleri, 2020: 257-258, 264).

İs Kanunu'nun 36. maddesi uyarınca "genel ve katma bütçeli dairelerle maballi idareler veya kamu iktisadi tessebbüsleri yahut özel kanuna veya Cumburbaskanhĭgr kararnamesine dayamlarak kurulan banka ve kuruluslar; asil ișverenler müteabbide verdikleri her türlü bina, köprü, hat ve yol inşasi gibi yapım ve onarm işlerinde çalssan işçilerden müteabhit veya tasseronlarca ücretleri ödenmeyenlerin bulunup bulunmadiğgnn kontrolü, ya da ücreti ödenmeyen işşinin başvurusu üzerine, ü̈retleri ödenmeyen varsa müteabhitten veya tasseronlardan istenecek bordrolara göre bu ücretleri bunlarm hakedişlerinden öderler". Dolayisiyla maddede sayllan idarelere de 198. maddeye dayalı olarak ödemeyi diğer eşe yapmaları emredilebilecektir. Ancak bu hususta madde 36 gereğince sorumluluğun, her hakediş dönemi için ücret alacaklarının en fazla üç aylık tutarıyla sınırlı olduğu, bundan fazlası hakkında adı geçen idarelere herhangi bir sorumluluk düşmediği göz

24 Ancak, sözleşme süresinin hitamına rağmen geçici iş ilişkisi sürdürüldüğünde; yasa gereği, geçici işçi çalıştıran işveren ile işçi arasında, sözleşmenin sona erme tarihinden itibaren belirsiz süreli iş sözleşmesi kurulmuş sayıldığından, artık işveren sıfatıyla sorumluluk başlayacaktır. Bu takdirde özel istihdam bürosunun sorumluluğu ise, işçinin geçici iş ilişkisinden kaynaklanan ücretinden, işçiyi gözetme borcundan ve sosyal sigorta primlerinden sözleşme süresiyle sınırlı bir sorumluluktur (İş K. m.7/f. 13).

${ }_{25}$ İş Kanunu m.7/f. 2-f bendi kapsamında kurulan geçici iş ilişkilerinde, geçici işçi çalıştıran işverenin işyerinde bir ayın üzerinde çalışan geçici işçilerin ücretlerinin ödenip ödenmediğini çalıştığ süre boyunca her ay kontrol etmesi, özel istihdam bürosunun ise ücretin ödendiğini gösteren belgeleri aylık olarak geçici işçi çalıştıran işverene ibraz etmesi gerekmektedir. Ödenmeyen ücretler var ise, geçici işçi çalıştıran işveren, bunlar ödenene kadar özel istihdam bürosunun alacağını ödemeyip mahsup esasıyla geçici işçilerin en çok üç aya kadar olan ücretlerini doğrudan işçilerin banka hesabına yatırmalıdır. 
önünde tutulmalıdır. Hükmün uygulanmasında kamu makamının işveren sıfatı taşıması gerekmediğinden, kendisi işçi çalıştırmadığı için işveren sıfatı bulunmayan kamu ihale makamları da 36. madde kapsamında yükümlüdürler (Mollamahmutoğlu, 2005: 421). Yine aynı madde uyarınca alt işverene iş veren işverenler de, alt işveren işçilerinin ücretlerinin ödenip ödenmediğini işçinin başvurusu üzerine veya aylik olarak resen kontrol etmekle, ödenmeyen ücretlerin bulunması halinde bunları hakedişlerden keserek işçilerin banka hesabına yatırmakla yükümlüdür (son f.).

\section{Ücretin Korunması ile İlgili Düzenlemelerin TMK 198. Madde Karşısındaki Durumu}

4857 sayılı İş Kanunu'nun 35. maddesi, işçilerin aylık ücretlerinin dörtte birinden fazlasının haczedilemeyeceğini veya başkasına devir ve temlik olunamayacağını öngörmektedir. Ancak yine aynı maddede söz konusu kısmen haczedilmezlik ve devir-temlik yasağı bakımından, işçinin bakmak zorunda olduğu aile üyeleri için hâkim tarafindan takdir edilecek miktarın bu paraya dahil olmadı̆̆ı belirtilmekte ve nafaka alacaklılarının hakları saklı tutulmaktadır. 6098 sayılı Borçlar Kanunu'nun 410. maddesi de benzer bir düzenleme içermekte olup, işçilerin ücretlerinin dörtte birinden fazlası haczedilemez, başkasına devredilemez ve rehnedilemez. Ancak işçinin bakmakla yükümlü olduğu aile bireyleri için hâkim tarafından takdir edilecek miktar, bu orana dahil değildir. Nafaka alacaklılarının hakları saklıdır.

Hemen belirtelim, TMK 198. maddede başlı başına nafaka düzenlenmemektedir. Türk Medeni Kanunu'nda düzenlenen nafakalar; boşanma davası açıldığında TMK m. 169 uyarınca re'sen alınacak geçici önlemler kapsaminda tedbir nafakası, boşanma halinde yoksulluk nafakası (m. 175), velayet kendisine birakılmayan eşin çocuğun bakım ve eğitim giderlerine katılması amacıyla istirak nafakası (m. 182) ve üstsoy-altsoy ile kardeşler arasındaki yardım nafakasıdır (m. 364). Ayrıca Kanun'un 197. maddesinde evlilik birliğinin korunması önlemleri kapsamında, ayrı yaşama hakkı olan eş lehine hükmedilebilecek tedbir nafakası düzenlenmiştir. O itibarla borçlulara ödemeyi diğer eşe yapmalarının emredilmesi halinde, alacağı talep yetkisi olan eşin durumu, hakkında böyle bir nafaka kararı verilmedikçe, esasen İş Kanunu 35. maddenin 2. cümlesinde yer alan "işçinin bakmak zorunda olduğu aile üyeleri için hâkim tarafindan takdir edilecek miktar" ile ilgilidir. İş Kanunu'nun 35. maddesi, söz konusu miktar1 ilk cümledeki haciz, devir ve temlik yasağına dair dörtte birlik kısmın dışında tutmuştur. Yani aylık ücretin haczi yahut devir ve temliki mümkün 1/4'lük kısmı belirlenir iken, işçinin bakmakla yükümlü olduğu aile üyeleri için takdir edilecek miktar zaten hariç tutulmaktadır (Kuru, 2013: 521-522; Çil, 2010: 718). Bunun ötesinde, hâkim TMK m. 198 uyarınca işçinin borçlusuna örneğin işverene ödemeyi işçinin eşine yapmasını emretme bakımından ücretin dörtte biri ile bağlı değildir. Ödemenin "tamamen veya kısmen" diğer eşe yapılması düzenlenmekte olup, eşin giderlere yapması gereken katkı tutarına bağlı olarak somut olayda ücretin tamamının diğer 
eşe ödenmesine hükmedilmesi de teorik olarak mümkündür. Bu takdirde işçinin diğer alacaklıları bakımından haciz koydurabilecekleri veya işçinin devir ve temlik edebileceği ücret tutarı bulunmayacaktır.

Fakat, ücret alacakları yönünden ödemenin tümüyle diğer eşe yapılmasının emredilmesi hususunda temkinli davranmak gerekmektedir. Bir kişinin evli olması ve birliğin giderlerine katılma yükümlülüğü tüm varını yoğunu ailesine sarf etmesini gerektirmemektedir. Kanunun öngördügü de eşlerin birliğin giderlerine güçleri oranında "katılmaları"dır. Bireyin kendi kişisel ihtiyaçlarının da bulunduğu göz ardı edilmemeli, bakım yükümlüsü eşin bizzat zarurete düşmesine yol açılmamalıdır (Gümüş, 2008: 185). Özellikle işçinin başkaca kaynaklardan düzenli kazancının bulunması halinde işverene ücretin tamamını diğer eşe ödemesi yönünde bir emir verilebilir ise de, o işyerindeki çalışması karşısındaki ücreti dışında hiçbir kazancı bulunmayanlar açısından TMK 198. maddenin kısmî ifaya dair ödeme emrini içerir şekilde uygulanması daha isabetlidir.

Ücrete başka bir alacaklının icra takibi nedeniyle önceden haciz konulmuş olsa bile, işverenin, bir yandan da mahkeme emri doğrultusunda diğer eşe ödeme yapması gerekmektedir. Yukarıda belirtildiği gibi işçi ücretinin "kısmen" haczi caiz olduğundan, ücretin tümünün haciz nedeniyle takip dosyasına yatırıldığı öne sürülemez. Tersine bir ihtimalde, ücretten TMK 198. madde uyarınca diğer eşe ödenecek kesinti var iken, bir üçüncü kişi alacaklının takibi nedeniyle ücret haczi gündeme gelir ise, diğer eşe ödenmesi gereken kısma dokunulmamalıdır (Atalay, 2003: 60-61). Neticede bu tutar aslında borçlunun ailesinin geçimi için gereken ve haczi caiz olmayan kısım mahiyetindedir.

\section{İşçilik Alacaklarının Diğer Eşe Ödenmesinin İş İlişkisine Etkileri}

İşveren, mahkemenin ödeme emri gereğince işçinin ücretini onun eşine ödediğinde işçiye tekrar ücret ödenmesi söz konusu olmayıp, işçi ücretinin ödenmediği iddiasıyla herhangi bir hak talebinde bulunamaz. İş Kanunu'nun m. 24/II-e bendine göre iş sözleşmesini ücretin ödenmediğinden bahisle derhal feshedemeyeceği gibi 34. madde uyarınca iş görmekten kaçınma hakkı da bulunmamaktadır. Fakat emir kısmî ödemeye ilişkin ise bakiyenin (başka bir haciz kesintisi gibi istisnaî durumlar hariç) işçinin kendisine ödenmesi gerekli olup, bu tutar bakımından işverenin işçiye karşı ücret borcu devam etmektedir. Ücretin ödenmeyen kısmı için haklı nedenle fesih yahut iş görmekten kaçınma hakkı saklıdır.

Ücret ve diğer işçilik alacaklarının işçinin eşine ödenmesi halinde de ücret bordrosu ve hesap pusulasının yine işçi adına düzenlenmesi gerekir. Brüt tutardan gelir, damga vergisi gibi yasal kesintiler yapıldıktan sonra ortaya çıan net tutar, ödeme emrindeki oran dahilinde eşe ödenmelidir. Mahkemece işverene gönderilecek ödeme emrinde katî bir meblağ yerine, oran belirtilmesi kanımızca daha isabetlidir. Tutar bazında belirleme yapıldığında işçinin ücret ve diğer 
gelirlerinde, keza vergi oranındaki değişmeler ödeme esnasında tereddütlere, uygulamada yeni uyuşmazlıklara yol açabilecektir. Isşçiye ücretin bir kısmının vadeden önce avans mahiyetinde ödenmesi gündeme geldiğinde de (TBK $\mathrm{m}$. 406/son f.) avans aynı esaslarla eşe ödenmelidir.

Öte yandan, işverenin ödeme emrine rağmen ücreti eşe ödememesi halinde işçiye karş1 ücret borcundan kurtulduğunu söylemek mümkün değildir. $\mathrm{Bu}$ durumda işçinin iş sözleşmesinden kaynaklanan ve kanunun kendisine tanıdığ1 hakları kullanması imkân dahilindedir. TMK m. 198 doğrultusunda borçlu işverene ödeme emri verilmesi, hiç şüphesiz işçinin eşini iş sözleşmesinin tarafi haline getirmemektedir; burada sözleşmenin nakli söz konusu değildir. İş ilişkisinin tarafı halen işçidir ve bu ilişki zemininde ücretin ödenmemesine, işverenin akde aykırılığına bağlı olarak kendisine tanınan iş görmekten kaçınma (İş K. m. 34) ve haklı nedenle fesih (İş K. m. 24/II) gibi hakları kullanabilmelidir. Borçlulara ait önlemler evlilik birliğinin korunmasına hizmet etmek amacıyla getirilmiştir. Aksine yorumla buradan borçlu işveren lehine bir sonuç çıkarılması hükmün amacına da aykırı düşer. Ödemenin kısmen veya tamamen işçi yerine onun eşine yapılacak olması, neticede işverenin ücret borcunu etkisizleştirmemekte yahut ona yeni bir içerik kazandırmamaktadır. Normal seyirde ücreti ödemeyen işverenin tâbi olduğu her türlü yaptırımın ve karşı karşıya kalabileceği hukukî sonuçların yine uygulanması gereklidir. Borçlu işveren de, iş ilişkisi bağlamında alacaklı işçisine karşı sahip olduğu defi ve itirazları, ifayı talep eden diğer eşe karşı da ileri sürebilmelidir ${ }^{26}$.

Ödemenin geç yapılması halinde gününde ödenmeyen ücretler ve kıdem tazminatı için geçerli olan mevduata uygulanan en yüksek faiz oranı işletilmelidir (4857 sayılı İş K. m. 34, 1475 sayılı İş K. m. 14). Eşe yapılacak ödeme, işverenin işçiye olan borcu yani işçinin işçilik alacağı çerçevesinde şekillenmektedir. Kanuna, akde uygun ifanın gerekleri ne ise eşe de o doğrultuda ve mahkemenin ödeme emri uyarınca ödeme yapılması gerekmektedir.

TMK 198. maddedeki düzenleme yukarıda incelendiği üzere diğer eşe, eşine ait alacağın doğrudan ifasını talep yetkisi sağlamakta, birliğin giderlerine katılmayan eşin alacaklı sıfatını ortadan kaldırmamaktadır. Mevcut borç ilişkisine (iş sözleşmesine) taraf olmayan eşe alacağ1 kendi nam ve hesabına talep yetkisi tanınmaktadır. ${ }^{27}$ Yetki ifa sonucuna yönelik olup, lehine ödeme emri verilen eşin bu yetkiyi bir başkasına devir imkânının olmadığı kanaatindeyiz. Oysa alacağın devrinde, alacak hakkı devralan alacakliya geçtiğinden onun da alacağı devretmesi ve borçlunun diğer devralana karşı yaptığı ödeme ile borçtan kurtulması mümkündür (TBK m. 186). Mahkemenin, eşlerden birinin evlilik birliğinin giderlerine katılmaması halinde borçluya vereceği emir, ödemeyi (tamamen veya

\footnotetext{
${ }^{26} \mathrm{Bu}$ konu eşin işçilik alacaklarının ispatı başlığında ayrıca ele alınacaktır.

27 Giderlere katılma yükümlülüğ̈unü yerine getirmeyen eşin tasarruf yetkisinin kalktı̆̆1, alacağın artık onun olmaktan çıktığ1 görüşü için bkz.; Bağce, 2015: 33.
} 
kısmen) "diğer eşe" yapmasından ibarettir. Bir başka üçüncü kişinin, diğer eşin iç ilişkide bu alacağ1 devrettiğinden bahisle işverenden ödemenin kendisine yapılmasinı talep edemeyeceği yahut böyle bir ihtimalde işverenin ödemeden kaçınabileceği görüşündeyiz. Eşin, diğer eşin giderlere katılmasını isteme hakkı şahsa sıkı sıkıya bağlı bir haktır, devredilemez (Gürpınar, 2013: 1314-1315). Zaten eş elde ettiği tutarı amacına uygun şekilde evlilik birliğinin giderleri, ailenin geçimi için kullanmak zorundadır (Yılmaz, 2016: 274). Ayrıca devirden bahisle, talep yetkisi olan eş yahut onun temsilcisi dışında bir kimseye ödeme yapıldığında ifanın talimata uygun yerine getirilip getirilmediğine dair yeni uyuşmazlıklar ortaya çıkabileceği gibi, meseleye yabancı çok sayıda kişinin de konuya dahil edilmesi kaçınılmaz olacaktır. Mahkeme kararı doğrultusunda diğer eșe tanınan ifayı talep ve kabul yetkisidir; borçlu da ancak mahkeme kararında gösterilen eşe veya onun yetkili temsilcisine ${ }^{28}$ yaptığ1 ödeme ile borcundan kurtulabilir ve emri yerine getirmiş sayılabilir.

İşçinin evlilik birliğinin giderlerine katılma yükümlülüğünü yerine getir(e)memesi, evlenme akdi ile ilgili olup, iş sözleşmesi bağlamında ve işverene karşı akde aykırı davranış anlamına gelmemektedir. Dolayısıyla işverenin bu durumu öne sürerek iş sözleşmesini geçerli ve haklı nedenle feshedebileceğinden söz edilmemek gerekir. Üstelik emrin verilmesinde yükümlü eşin kusuru da belirleyici olmadığına göre, işveren işçisine karşı içten içe dahi olumsuz bir değerlendirmede bulunmamalıdır. İşverence iş sözleşmesinin işçinin başkaca davranışları veya yeterliliği ile ilgili nedenlerle feshedildiği hallerde, vaktiyle onun hakkında TMK m. 198 uyarınca böyle bir emir verilmiş olması, feshin geçerliliği/ haklılığı hususunda ispat gücü de taşımamalıdır. Mesele ayrı alanlarla, farklı hukukî ilişkilerle ilgilidir ve işçiye karşı adeta bir "koz" gibi kullanılmasına cevaz verilmemelidir. Kaldı ki geçici tedbir yargılaması sonucunda ortada tam ispata dayalı maddî anlamda kesin hüküm niteliğinde bir karar da bulunmamaktadır.

\section{Yargılama ile İlgili Hususlar}

\section{Görev ve Yetki}

4787 sayll Aile Mahkemelerinin Kuruluş, Görev ve Yargılama Usullerine Dair Kanun'un 4. maddesine göre Türk Medeni Kanunu'nun Üçüncü Kısım hariç olmak üzere İkinci Kitabındaki düzenlemelerden kaynaklanan talep ve uyuşmazlıklar hakkında aile mahkemeleri görevlidir. İnceleme konumuz olan eşin borçlularına emir verilmesi de bu kapsamdadır. Diğer eşe ödenmesi talep edilen bir işçilik alacağı ve emir verilecek borçlu işveren olsa bile, uyuşmazlık iş hukukundan ve iş sözleşmesinden değil; aile hukukundan ve evlenme akdinden kaynaklanmaktadır. Taraflar da işçi ve işveren olmayıp, eşlerdir. Keza burada karar üçüncü kişi aleyhine değil, birliğin giderlerine katılmayan eş aleyhine verilmektedir; ancak önlemin

${ }^{28}$ Tahsil için temsil yetkisi verilmesi, alacağın temlikinden farklı bir müessesedir. 
konusunu, aleyhine karar verilenin üçüncü kişilerdeki alacağı oluşturmaktadır (Budak, 2000: 162).

Türk Medeni Kanunu'nun 201. maddesine göre birliğin korunması önlemleri konusunda eşlerden birinin yerleşim yeri mahkemesi yetkilidir (f. 1). Eşlerin ortak yerleşim yerinin bulunmaması ve her ikisinin de önlem alınmasını istemesi halinde ise, yetkili mahkeme ilk istemde bulunan eşin yerleşim yeri mahkemesidir (f. 2). Önlemlerin değiştirilmesi, tamamlanması veya kaldırılması hususunda önlem kararını veren mahkeme yetkilidir. Fakat son fikrada her iki eşin de yerleşim yerinin değişmesi halinde yetkili mahkeme yine eşlerden herhangi birinin yerleşim yeri mahkemesi olarak düzenlenmiştir.

\section{Eşin İşçilik Alacaklarının İspatı ve Hüküm}

Geçici hukukî korumalarda kural olarak tam ispat değil, yaklaşık ispat aranmaktadır ve tam ispata nazaran düşürülmüş bu ispat ölçüsünde hâkim ispatı gereken vakıay1 gerçeğe yakın, kuvvetle muhtemel görmelidir (Pekcanıtez ve diğerleri, 2020: 353, 571; Musielak, 2005: 273-275; Albayrak, 2013: 69).

TMK m. 198 uyarınca hâkimin eşin borçlularına, ödemeyi diğer eşe yapmalarını emredebilmesi için öncelikle, eşin birliğin giderlerine katılmadığının ortaya konması gereklidir. Daha önce TMK m. 196/I veya 197/II uyarınca eşin yapacağ1 parasal katkı belirlenmiş ise artık bu yön çekişmeli değildir. Elbette aynı başvuruda hem belirlemenin yapılması hem de borçlulara emir verilmesi istenebilir (Yılmaz, 2016: 257). Eşin birliğin giderlerine katılmadı̆̆1 hususunun açıklık kazanmasından öte, onun bir alacağının ve borçlusunun tespit edilebilmesi de gerekmektedir. İşçilik alacakları hakkındaki ödeme emri taleplerinde ve kararlarında, iş hukukunun normatif düzenlemeleri, somut olayın özelliklerine göre üçlü iş ilişkileri, bu bağlamda iş ilişkisi taraflarının hangi borçtan ne ölçüde sorumluluk taşıdıkları gibi hususlar dikkate alınmalıdır. Giderlere katılma yükümlülügünü yerine getirmeyen eşe karşı, diğer eş tarafindan mahkemeye başvurulduğu için, bu yargılamanın tarafı, eşe borçlu olan üçüncü kişiler değildir. Söz konusu alacağın varlığının, miktarının ve borçlu sıfatının tespiti bakımından üçüncü kişinin taraf olmadığ1 bir davada verilen hükmün onun aleyhine kesin hüküm etkisi göstermesi beklenemez. Ödemenin kendisine yapılmasını talep eden taraf, eşinin talebe esas alacaklarının neler olduğunu ortaya koyacak iddia ve delillerini yargılama esnasında sunmalıdır. Mahkeme de bu yönde bir kanaate ulaştığında üçüncü kişiye ödemenin yapılmasını emredebilecektir. Fakat eşin borçluları, böyle bir alacağın var olmadığı yahut ödeme emrinde belirtilen tutarda olmadığı iddiasıyla ödemeden kaçınırlar ise, artık böyle bir uyuşmazlık lehine ödeme emri verilen eş ile diğer eşin "borçluları" arasında sonraki bir davada ele alınıp çözümlenmelidir. Bu davada, daha önce TMK m. 198'e dayalı yargılamada verilen karar HMK 303. madde uyarınca kesin hüküm teşkil etmemektedir. Çünkü bir davaya ait kesinleşmiş hükmün diğer davada maddî anlamda kesin hüküm oluşturabilmesi için, her iki davanın taraflarının, dava sebeplerinin ve ilk davanın 
hüküm fikrası ile ikinci davaya ait talep sonucunun aynı olması gerekir (HMK m. 303/f. 1). Ele aldığımız konuda ise bu unsurlar mevcut değildir. Zaten ortada maddi anlamda kesin hüküm teşkil eden bir karar bulunmamaktadır; karar kaldırılabilir, değiştirilebilir niteliktedir.

TMK 198. madde uyarınca verilen karar tarihinde işverenin, işçisine karş1 kendi borcu mevcut olsa bile, ödeme emrinin işverene tebliği tarihinde bu borç ifa vb. bir sebeple sona ermiş ise işveren, diğer eşe tekrar ödemeye zorlanamaz. Kald1 ki TMK 198. madde kapsamında müstakbel alacaklar da yer almaktadır. Karar ve kararın işverene tebliği tarihinde müeccel bir işçilik alacağının, daha sonra ifa diş1 bir sebeple sona ermesi ihtimal dahilinde olduğundan, işverenin borcun sona ermesine rağmen diğer eşe ödeme yükümlülüğünün bulunmadığ1 kanaatindeyiz. Örneğin; kıdem tazminatının taksitle ödenmesi anlaşması yapılan bir olayda, işverene izleyen taksitlerin diğer eşe ödenmesi emredildiğinde, ve fakat vade tarihinde işverenin bu borcunu, işçiden olan bir alacağı ile takas etmesi halinde işverenin diğer eşe ödemekle yükümlü olduğu bir tutar bulunmamaktadır. Borçlu asıl alacaklıya karşı sahip olduğu itiraz ve defileri diğer eşe karşı ileri sürebilir (Ayan, 2004: 255; Öztan, 2015: 375). Eşlerden birinin evlilik birliğinden doğan yükümlülügünü yerine getirmemesi, bu ilişkiye yabanc1 üçüncü kişinin kendi borç ilişkisi bağlamında maddî hukuktan kaynaklanan yahut usulî savunma sebeplerini kullanmasını etkisizleştirmemelidir. Biz TMK 198. maddedeki düzenlemenin alacağın devri mahiyetinde olmadığ1 görüşüne katıldığımızdan, TBK m. 188’e göre "borçlu, devri ögrendiğ anda muaccel olmayan alacağın, devredilen alacaktan önce veya onunla ayn anda muaccel olması koșuluyla borcu ile takas edebilir" şeklindeki sinırlamanın da uygulama alanı bulmayacağını düşünmekteyiz.

Benzer şekilde, TMK 198. madde eşin (işçinin) alacaklı sıfatını ortadan kaldırmadığına ve tasarruf yetkisini sınırlamadı̆̆ına göre, kanımızca işçinin söz konusu alacağı üzerinde ibra, feragat, sulh gibi bir yolla tasarrufta bulunmas1 mümkündür ${ }^{29}$. Göz ardı edilmemelidir ki, tasarruf yetkisinin sinırlanması kanunun ayrı bir maddesinde başlı başına düzenlenmektedir: "Ailenin ekonomik varlı̆̆mın

29 Öztan, düzenlemenin alacağın temliki olmadığını, eşin alacaklı sıfatını koruyup diğer eşe sadece ifayı talep yetkisi tanındığını tespit etmesine rağmen, borçlu eşin alacağı temlik etmesinin, ibra sözleşmesi yapmasının ancak katılma payına ilişkin alacak hakkına sahip eşin rızasıyla geçerli olduğunu ileri sürmektedir (2015: 376). Aynı yönde Gümüş, 2008: 186. Yılmaæ, alacaklı eşin artık alacak hakkından feragat edemeyeceği, hukukî işlemler yoluyla tasarrufta bulunamayacağ1 görüşündedir (2016: 271-272). Ancak öte yandan yazar, TMK m. 198'e dayanarak talimat karar verilmesinden sonra alacağm temlik edilmis veya rehnedilmis olmas halinde, alacağın üzerindeki talimatla yüklü olarak rehin ve temlike edileceğini dile getirmektedir (Yllmaz, 2016: 275). Yargitay 3. HD.nin 18.10.2007 T., 14193/14996 say1l kararinda da Medeni Kanun'un 198. maddesinde düzenlenen ve birliği korumay amaçlayan bu önlemle, "davalu kocanin alacaklar üzerindeki tasarruf salabiyeti kaldrrlmakta olduğundan" önemli nedenler halinde bu önleme başvurulmalıdir denilmektedir (lexpera.com.tr Erişim tarihi: 04.12.2021). 
korunmasi veya evlilik birlï̆inden doğan mali bir yükü̈mlülüğ̈̈n yerine getirilmesi gerektirdiği

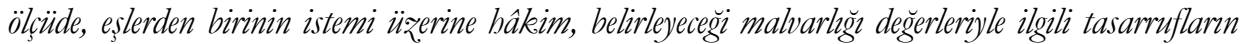
ancak onun masiyla yapılabileceğine karar verebilir' (TMK m. 199/1). Bu düzenleme dahi eşin tasarruf yetkisini tümüyle ortadan kaldıran bir içerik taşımamakta, hâkim tarafindan saptanacak belirli malvarlığı değerlerinden ibaret olmak üzere, tasarruf işlemlerini diğer eşin muvafakatine bağlı kılarak sınırlamaktadır.

Sinırlayıc hükümler dar yoruma tâbidir ve 199. maddenin 198. maddeye dahil olacak şekilde genişletilerek yorumlanması bu esasa da uygun düşmemektedir. Tasarruf yasağı - tasarruf yetkisinin sinırlanması farklı kavramlar olup, tasarruf yasağında hakkın kendisi tasarruf edilebilir nitelik taşımadığından hakkın tasarruf işlemine konu edilmesi mümkün değildir. Tasarruf sınırlamasında ise esasen tasarruf edilebilir nitelikte bir hak bulunmasına rağmen hak sahibinin tasarruf yetkisi sınırlanmış, bir başka kişinin veya makamın iznine, onayına bağlı kilınmıştır (Hamamcıŏlu Vardar, 2014: 352 vd.). Tasarruf yasağına rağmen yapılan bir tasarruf işlemi geçersiz iken, tasarruf yetkisi sınırlamasına aykırı işlem askıda hükümsüzdür ve onay gibi tamamlayıcı unsur gerçekleştiğinde işlem hüküm ve sonuçlarını doğurur (Hamamcioğlu Vardar, 2014: 355, 357-358). Bu doğrultuda 199. madde belirli malvarlığ1 değerleri bakımından tasarruf işlemini diğer eşin rızasına bağlayarak eşin tasarruf yetkisini sınırlamaya yönelik özel bir hükümdür.

Yine genel olarak üçüncü şahsın ifayı kendi adına talep yetkisinin bulunduğu hallerde alacaklının alacak üzerinde tasarruf yetkisi sürmektedir (Akyol, 2007: 146 vd.). Mahkemenin 198. madde kapsamındaki kararı eşin tasarruf yetkisinin sınırlanması yönünde olmayıp, alacağın mevcudiyeti halinde ifa zamanında ödemenin diğer eşe yapılmasıdır. Dolayısıyla, alacak (alacaklı eşe ifa dışında) herhangi bir sebeple sona ermiș yahut ișçi alacak üzerinde tasarrufta bulunduğu için borç ortadan kalkmış ise, işverenin diğer eşe karşı da sorumluluğu bulunmamaktadır; yeter ki hakkın kötüye kullanılması yahut muvazaa söz konusu olmasın. Giderlere katılma yükümlülüğ̈ünü yerine getirmeyen eşin bu alacağ1 üzerinde diğer tasarruf işlemlerini sınırlamak amacıyla, 198. maddeye dayalı başvuruda 199. madde uyarınca sınırlamanın da birlikte talep edilmesi ve bu yönde karar alınması gerektiği görüşündeyiz ${ }^{30}$.

Ayrıca belirtelim; TMK 198. maddeyi de kapsayan evlilik birliğinin korunmasına yönelik önlemler Hukuk Usulü Muhakemeleri Kanunu'nun çekişmesiz yarg1 işlerini sıraladığ1 382. maddesindeki listede sayılmamıştır. Dolayısıyla müesseseye bir çekişmesiz yargı işi olarak bakılmaması gerekir (Aksi görüş Budak, 2005: 131). Eşler arasında bir çekişmenin bulunduğu da tartışmasızdır. Talepte bulunan eş, diğerinin evlenme akdinden kaynaklanan yükümlülüğünü yerine getirmediği, dolayısıyla kendisinin katılma payına ilişkin alacağının bulunduğu

30 TMK 198 dişında 199. maddedeki tedbirin de istem üzerine birlik giderlerinin ifasını sağlamak üzere, şartları varsa, yardımc bir tedbir olarak uygulanabileceği görüşü için bkz.; Gümüş, 2008: 181. Ayrıca bkz.; Yılmaz, 2016: 265; Hausheer ve diğerleri, 1999: 605 N. 12d. 
iddiasına dayanmaktadır. Önlemler ayrı bir yargılamayı gerektirmektedir (Erişir, 2013: 267). Hâkim elbette geçici hukukî korumanın şartlarının gerçekleşip gerçekleşmediğini araştırıp inceleyecektir ve geçici hukukî korumaya ilişkin yargılama yapılması işin esasının incelenmesine engel değildir (Akkan, 2007: 62). İçtihatlarda da talepte bulunan "davacı", karşı taraftaki eş ise "davalı" olarak anılmaktadır ${ }^{31}$ ve borçluya ödeme emri verilmesinin hasımsız olarak (çekişmesiz yargı işi mahiyetinde) görülmesi mümkün değildir (Gençcan, 2019: 416).

Hukukî dinlenilme hakkı geçici hukukî korumalar açısından da riayet edilmesi gerekli usulî bir temel ilkedir (Özekes, 2003: 212). Burada birliğin giderlerine katılmadığ iddia edilen eşin hem buna karşı savunma hakkını kullanabilmesi hem de 3. kişiden talebe konu bir alacağının bulunup bulunmadığının değerlendirilmesi bakımından cevap ve ispat hakkının tanınması büyük önem taşımaktadır. Uygulamada da evlilik birliğini koruyucu önlemlerin husumetin diğer eşe yöneltildiği bir yarg1lamada duruşmalı olarak, tarafların gösterdikleri tüm delillerin toplanıp değerlendirilmesi neticesinde karara bağlandığı belirtilmektedir (Bkz. İnan Günay, 2018: 93). Geçici hukukî korumalarda menfaat dengesi önem taşımaktadır ve ölçülülük ilkesi ile her iki tarafın azamî yararını gözetecek yöntemin belirlenip izlenmesi gereklidir (Pekcanıtez ve diğerleri, 2020: 569).

$\mathrm{Bu}$ önleme karar verilmesi asıl yargılamaya bağlanmadığından bağımsız özelliktedir ve işin esasına girilerek geçici mahiyette de olsa bir nihaî karar verilmektedir. Dolayısıyla karara karşı kanun yoluna başvurulabilecek ve kararın denetimi sağlanabilecektir (Erişir, 2013: 281; İnan Günay, 2018: 37). Nitekim Türk Medenî Kanunu'nda bu hallerde mahkemece kesin olarak karar verileceğinden söz edilmemektedir. Ancak Hukuk Muhakemeleri Kanunu'nun 362. maddesine göre (-f bendi) geçici hukukî korumalar hakkında verilen kararlar temyiz edilemeyen kararlardan olduğu için başvurulacak kanun yolu istinaftır.

\section{Sonuç}

Türk Medeni Kanunu'nun 198. maddesinde düzenlenen evlilik birliğinin giderlerine katılma yükümlülüğünü yerine getirmeyen eşin borçlularına, ödemeyi diğer eşe yapmalarının hâkim tarafından emredilmesi, evlilik birliğini koruma amacı taşıyan aile hukukuna özgü geçici bir önlem, geçici hukukî korumadır. Düzenleme kadın/erkek ayrımıla cinsiyet temelli bir hüküm olmayıp, birliğin giderlerine katılma yükümlülüğünü yerine getirmeyen hangi eş ise, ona karşı işletilebilecektir.

$\mathrm{Bu}$ önleme, ancak yükümlü eşin para alacaklarının bulunduğu hallerde başvurulabilecektir. Maddede yer alan "ödeme" ifadesi de para borçlarının esas alındığını göstermektedir ve bu değerlendirme sırf lafzî bir yorumun sonucu değildir. Özellikle alacaklının kişiliğinin önem taşıdığı yahut ifa yerinin belirli bir yerle sinırlı şekilde belirlendiği borç ilişkilerinde de üçüncü kişiye böyle bir emir verilmesi, o

31 Örneğin Yargitay 2. HD. 11.04.2013 T., 2012/11935 E., 2013/10209 K. (lexpera.com.tr Erişim tarihi: 19.02 .2020$)$. 
ilişkiye kanunun öngörmediği bir müdahale anlamı taşır ve eşler arasında evlilik birliğinden kaynaklanan bir uyuşmazlık, üçüncü kişilerin özel hayatlarında, iş hayatlarında ve hukukî durumlarında yeni, ciddî sorunlara yol açabilir.

Kanun ödemenin diğer eşe yapılmasının emredilebilmesi için alacağın muaccel olması şartını aramamaktadır. Bilakis söz konusu önlem, müeccel alacaklar ve devrî/dönemsel ödemeler bakımından daha etkili, pratik ve işlevseldir. Bu bağlamda kira alacakları ve iş ilişkisinden doğan işçilik alacakları öne çıkmaktadır. İşçilik alacaklarının başında gelen ücretin yanında kıdem-ihbar tazminatı, sendikal tazminat, ikramiye-prim ücret ekleri, fazla mesai ücreti, hafta ve bayram tatili çalışma ücreti gibi ödemelerin diğer eşe yapılması emredilebilecektir. İşin görülmesinin gerektirdiği masraflar için işçiye verilen para ise bu kapsamda değildir. İş ilişkisinin, sözleşmenin tarafları işçi ile işverendir, fakat ödeme artık işçinin eşine yapılmaktadır. Alacaklı sıfatı yine iş sözleşmesinin tarafı olan eştedir. Diğer eş, geçici bir süre hâkimin kararına istinaden ifayı talep yetkisi elde etmektedir. Ortada bir yargisal devir (kazaî temlik) bulunmamaktadır. Zaten verilen karar geçici olup, şartlar değiştiğinde hâkim, eşlerden birinin istemi üzerine kararında değişiklik yapabilmekte ya da sebebi sona ermişse önlemi kaldırabilmektedir (m. 200). Geçici hukukî korumalar ile yargısal devir müessesesinin birbirine karıştırılmaması gereklidir. Önlem kapsamında kararın mahkemece verilmesi ve konunun bir borcun ilişkideki alacaklı haricinde üçüncü kişiye ifasıyla ilgili olması alacağın devri demek değildir.

Ödemenin diğer eşe yapılması işçi bakımından ücretinin ödenmediği yahut eksik ödendiği iddiasıyla iş sözleşmesinin haklı feshine (İş K. m. 24/II-e) imkân vermez. İşçi İş Kanunu'nun 34. maddesine göre iş görme borcunu yerine getirmekten de kaçınamaz. Ancak işveren diğer eşe ödeme yapmamışsa işçinin sözleşmeyi fesih ya da iş görmekten kaçınma hakkı saklıdır. Ödemenin diğer eşe yapılması emrinin tebliğine rağmen para işçinin kendisine ödenir ise, işveren diğer eşe tekrar ödeme yapmak zorunda kalacaktır.

İfanın diğer eşe yapılması özel sektör işverenleri kadar kamu işverenine yönelik olarak da emredilebilir. İşçilik alacaklarından borçlu sıfatıyla sorumluluk taşıması hukuken mümkün asıl işverenler, geçici işverenler, kamu ihale makamları gibi diğer üçüncü kişilere de, iş mevzuatının düzenlediği esaslar doğrultusunda ve getirdiği sınırlamalar göz ardı edilmeksizin, bu yönde emir verilebilir.

Söz konusu geçici hukukî koruma, alacaklı sıfatında bir değişiklik yaratmadığından alacaklı işçinin sahip olduğu tasarruf yetkisi de kanımızca varlığını korumaktadır. Tasarruf yetkisinin sinırlanması TMK 199. maddede ayrıca düzenlenmektedir ve sınırlayıcı hükümlerin dar yoruma tâbi tutulması gereklidir. 199 . madde dahi eşin tasarruf yetkisini bütünüyle kaldırmamakta, belirleyeceği malvarlı̆̆1 değerleriyle sınırlı olmak üzere tasarruf işlemlerinin yapılmasını diğer eşin rızasına bağlamaktadır. Dolayısıyla 198. maddeye dayalı kararın daha etkin koruma sağlaması açısından, o alacak hakkı üzerinde 199. madde uyarınca tasarruf yetkisinin sınırlanmasının birlikte talep edilmesinde ve bu yönde karar tesisinde yarar bulunmaktadir. 


\section{KAYNAKÇA:}

Akıntürk, T. (1967) Aile Hukuku Dersleri, Ankara.

Akıntürk, T./Ateş, D. (2016) Türk Medenî Hukuku Aile Hukuku, İkinci Cilt, İstanbul: Beta Basim.

Akkan, M. (2007) "Medenî Usûl Hukukunda Etkin Hukukî Koruma”, MİHDER, 6, 29-68.

Aktay, N./Arıcı, K./Kaplan-Senyen, E.T. (2007) İş Hukuku, Ankara: Seçkin Yayincilik.

Akyiğit, E. (2020) Bireysel İş Hukuku Ders Kitabı, Ankara: Seçkin Yayıncılık.

Akyol, Ş. (2007) Üçüncü Şahsın İfayı Kendi Adına Talep Yetkisi, İstanbul: Vedat Kitapç1lik.

Alp, M. (2012) 'Yeni Türk Ticaret Kanunu'na Göre Bölünme, Birleşme ve Tür Değiştirmenin İş İlişkilerine Etkisi” Çalışma ve Toplum, 32, 51-74.

Atalay, O. (2003) “Türk Medenî Kanunu’nda Aile Hukuku Mal Rejimlerine İlişkin Hükümlerin Takip Hukuku Bakımından Değerlendirilmesi’, Medenî Usul ve İcra-İflas Hukukçuları Toplantısı - I, 9-10 Kasım 2002, Eskişehir: Anadolu Üniversitesi Hukuk Fakültesi Yayınları.

Ayan, S. (2004) Evlilik Birliğinin Korunması, Ankara: Türkiye Barolar Birliği Yayinlar1.

Bağce Arda, H. D. (2015) Alacağın Devri ve Diğer Hukukî Kurumlarla Karşılaştırılması, İstanbul Kültür Üniversitesi SBE. YL Tezi, İstanbul.

Budak, A. C. (2000) Medeni Usul Hukukunda Üçüncü Kişilerin Haklarının Korunmas1, İstanbul: Beta Basim.

Budak, A. C. (2005) "Türk Hukukunda Çekişmesiz Yargı”, Medenî Usul ve İcraİflâs Hukukçuları Toplantısı - IV, 30 Eylül - 11 Ekim, Ankara.

Çelik, N./Caniklioğlu, N./Canbolat, T. (2020) İş Hukuku Dersleri, İstanbul: Beta Basim.

Çil, Ş. (2010) İş Hukukunda İşçinin Ücreti, Ankara: Turhan Kitabevi.

Çil, Ş. (2020) İş Uyuşmazlıklarında Yargıtay Uygulamaları, Ankara: Yetkin Yayınları.

Dayınlarlı, K. (2010) Borçlar Kanununa Göre Alacağın Temliki, Ankara: Dayınlarlı Hukuk Yayınları.

Deren Yıldırım, N. (1996) Kesin Hükmün Subjektif Sınırları, İstanbul: Alfa Basım.

Ekonomi, M. (2008) "Asıl İşveren - Alt İşveren İlişkisinin Kurulması ve Sona Ermesi”, Legal Vefa Toplantıları (II) Prof. Dr. Nuri ÇELIKK’e Sayg1, Türk İş Hukukunda Ǘçlü İlişkiler, Mart, İstanbul.

Erdoğan, İ. (1991) “Alacağın Temliki ve Kiymetli Evrakın Devri”, Prof. Dr. Jale G. Akipek'e Armağan, Konya: Selçuk Üniversitesi Hukuk Fakültesi Yayınları.

Eren, F. (2017) Borçlar Hukuku Genel Hükümler, Ankara: Yetkin Yayınları.

Erişir, E. (2013) Geçici Hukukî Korumanın Temelleri ve İhtiyatî Tedbir Türleri, İstanbul: On İki Levha Yayıncilik.

Eyrenci, Ö./Taşkent, S./Ulucan, D. (2004) Bireysel İş Hukuku, İstanbul: Legal Yayinc1lik. 
Feyzioğlu, F. N. (1977) Borçlar Hukuku Genel Hükümler, C.II, İstanbul: İstanbul Üniversitesi Yayınları.

Gençcan, Ö. U. (2016) Aile Mahkemesi Davaları, Ankara: Yetkin Yayınları.

Gençcan, Ö. (2019) Evliliğin Genel Hükümleri, Ankara: Yetkin Yayınları.

Göksu, T. ve Heberlein, A. (2016) "Personen- und Familienrecht Partnerschaftsgesetz Art. 1-456 ZGB - PartG”, CHK - Handkommentar zum Schweizer Privatrecht, Art. 177, Zürich - Basel - Genf: Schulthess Juristische Medien AG.

Gümüş, M. A. (2008) Teoride ve Uygulamada Evliliğin Genel Hükümleri ve Mal Rejimleri, İstanbul: Vedat Kitapçılık.

Gürpınar, D. (2013) “Eşlerin Evlilik Birliğinin Giderlerine Katılma Borcu”, Yaşar Üniversitesi E-Dergisi, C. 8, Özel say1, 1293 - 1340. https://journal.yasar.edu.tr/arsiv/vol-8/ armagan-sayi-vol-8/

Güven, K. (1998) 4320 Sayll “Ailenin Korunmasına Dair Kanun”un Getirdiği Hukuki Tedbirler” GÜHFD, C. 2, S. 1-2, Prof. Dr. İhsan Tarakçıŏlu'na Armağan. http://webftp.gazi.edu.tr/hukuk/dergi/ 2_1.pdf

Güzel, A. ve Heper, H. (2017) "Sürekli İstihdamdan Geçici Atipik İstihdama!...: Mesleki Amaçlı Geçici İş İlişkisi”, Çalışma ve Toplum, 52, 11-58.

Hamamcioğlu Vardar, G. (2014) Medenî Hukuk’ta Tasarruf İşlemi Kavramı, İstanbul: On İki Levha Yayıncilik.

Hausheer, H./Reusser, R./Geiser, T. (1999) Die Wirkungen der Ehe im allgemeinen, Art. 159-180 ZGB, Schweizerisches Zivilgesetzbuch, Das Familienrecht, Das Eherecht, Berner Kommentar Band/Nr. II/1/2, 589-606, Bern: Stämpfli Verlag AG.

İnan Günay, E. (2018) Aile Hukukunda Geçici Hukukî Himaye Tedbirleri, Ankara: Adalet Yayinevi.

İnci, R. (2019) "Calışan Kadinlarda Şiddet Algısı ve Bu Algıda Ekonomik Şiddetin Yeri" Uluslararası Yönetim Akademisi Dergisi, 3, 189-206.

İyilikli, A.C. (2011) Borçlunun Üçüncü Kişilerdeki Mal, Hak ve Alacaklarının Haczi, Ankara Üniversitesi SBE. Doktora Tezi, Ankara.

Kahveci, N. (2007) “4320 Sayılı Ailenin Korunmasina Dair Kanun’da 5636 Sayılı Kanunla Yapılan Değişiklikler”, İzBD, 3, 272 - 312.

Kilıçoğlu, M. A. (2010) Borçlar Hukuku, Genel Hükümler, Ankara: Turhan Kitabevi.

Knoepfler, F. (1988) “İsviçre'de Yeni Aile Hukuku Üzerinde Açılklamalar” (çev. A. Özer), Yargitay Dergisi, 1-2, 121-128.

Koçhisarlıŏ̆lu, C. (1991) “İsviçre'de Evlilik Birliği Hukuku’ndaki Son Gelişmeler”, Prof. Dr. Jale G. Akipek'e Armağan, Konya: Selçuk Üniversitesi Hukuk Fakültesi Yayınları.

Kuru, B. (2001) Hukuk Muhakemeleri Usulü, C. IV, İstanbul: Demir Yayıncılık.

Kuru, B. (2013) İcra ve İflas Hukuku El Kitabı, Ankara: Adalet Yayınevi.

Mollamahmutoğlu, H. (2005) İş Hukuku, Ankara: Turhan Kitabevi. 
Narmanlıoğlu, Ü. (2014) İş Hukuku Ferdi İş İlişkileri I, İstanbul: Beta Basım.

Oğuzman, M.K. (1979) Borçlar Hukuku Dersleri, İstanbul: İstanbul Üniversitesi Yayınlar1.

Oğuzman, M.K. (1987) Borçlar Hukuku Dersleri, İstanbul: Filiz Kitabevi.

Özekes, M. (2003) Medeni Usul Hukukunda Hukuki Dinlenilme Hakk1, Ankara: Yetkin Yayınlar1.

Özkaraca, E. (2008) İşyeri Devrinin İş Sözleşmelerine Etkisi ve İşverenlerin Hukuki Sorumluluğu, İstanbul: Beta Basim.

Öztan, B. (2015) Aile Hukuku, Ankara: Turhan Kitabevi.

Pekcanıtez, H./Atalay, O./ Sungurtekin Özkan, M./Özekes, M. (2008) İcra ve İflâs Hukuku, Ankara: Yetkin Yayınları.

Pekcanıtez, H./Atalay, O./Özekes, M. (2020) Medenî Usûl Hukuku Ders Kitab1, İstanbul: On İki Levha Yayıncilik.

Reisoğlu, S. (2014) Türk Borçlar Hukuku Genel Hükümler, İstanbul: Beta Basım.

Samat, M. (2010) Evlilik Birliğinin Korunması, Ankara Üniversitesi SBE. YL Tezi, Ankara.

Schmid, U. (2016) ZGB Kommentar Schweizerisches Zivilgesetzbuch, 342-345, Zürich: Orell Füssli Verlag.

Schwander, I. (2014) Basler Kommentar, Zivilgesetzbuch I, Art. 1-456 ZGB, Basel: Helbing Lichtenhahn Verlag.

Soyer, A. (2018) "Aile Mahkemeleri Uygulaması Bağlamında Evlilik Birliğinin Devamı Sırasında Birliğin Korunması Amacıyla Alınabilecek Önlemler”, İzmir Medeni Hukuk Günleri - II, Aile Hukuku Sempozyumu, Bildiri Özetleri, 2728 Nisan, İzmir.

Soyer, P. (2010) “İş İlişkisinin Kurulması, Hükümleri ve İşin Düzenlenmesi”, Milli Komite Yargıtay'ın İş Hukuku ve Sosyal Güvenlik Hukuku Kararlarının Değerlendirmesi 2008, Ankara.

Sungurtekin Özkan, M. (2003), “Medenî Kanun'un Aile Hukuku Alanında Getirdiği Değişikliklerin Medenî Usul Hukuku Bakımından Düşündürdükleri’, Medenî Usul ve İcra-İflas Hukukçuları Toplantısı - I, 9-10 Kasım 2002, Eskişehir.

Sümer, H. H. (2006) İş Hukuku, Konya: Mimoza Yayınları.

Süzek, S. (2018) İş Hukuku, İstanbul: Beta Basım.

Şener, E. (1998) İçtihatlı-Açıklamalı Türk Medeni Kanunu, 1. Cilt, Ankara: Seçkin Kitabevi.

Tekinay, S.S. (1984) Türk Aile Hukuku, İstanbul: Beta Basım.

Tekinay, S.S./Akman,S./Burcuoğlu, H./Altop, A. (1993) Tekinay Borçlar Hukuku Genel Hükümler, İstanbul: Filiz Kitabevi.

Uzun Birinci, T. (2016) "Evlilik Birliğinin Korunması için Borçlulara Talimat Verilmesi” LHD, C. 14, S. 163, 3727 - 3749.

Üstündağ, S. (1995) İcra Hukukunun Esasları, İstanbul: Alfa Basım Yayım. 
Velidedeoğlu, H.V. (1960) Türk Medeni Hukuku, Aile Hukuku, C. II, İstanbul: Sermet Matbaasi.

Velidedeoğlu, H. V. (1948) Medeni Hukukun Umumi Esasları, İstanbul: İstanbul Üniversitesi Yayınları.

von Tuhr, A. (1983) Borçlar Hukuku (çev. C. Edege), C. 1-2, Ankara: Yargitay Yayinlar1.

Y1lmaz, C. (2016) Birlikte Yaşamaya Ara Verilmesi, Ankara: Adalet Yayınevi.

Yılmaz, E. (2001) Geçici Hukukî Himaye Tedbirleri, C. 1, Ankara: Yetkin Yayınları.

Yılmaz Kılıçoğlu, K. (2015) “Evlilik Birliğinin Korunması”, TBB Dergisi, S. 120, 423 - 464.

Yılmaz, S. ve Bayramoğlu, N.Ş. (2016) "Eşin Tasarruf Yetkisinin Kısıtlanması", Cevdet Yavuz’a Armağan, C. III, MÜHF-HAD, Özel Say1, 3143-3162.

Zevkliler, A./Ertaş, Ş./Havutcu, A./Aydoğdu, M./Cumalıŏ̆lu, E. (2013) Borçlar Hukuku Ana İlkeler, İzmir: Barış Yayınları Fakülteler Kitabevi.

www.kazanci.com

www.lexpera.com.tr 